\title{
Türkiye'de Faaliyet Gösteren Doğal Gaz Dağıtım Firmalarının Veri Zarflama Analizi Yöntemiyle Etkinliğinin Araştırılması ${ }^{1}$
}

\section{Research of Turkish Natural Gas Distribution Companies' Efficiency with the DEA Methods}

\author{
Ömür Cem HÜNERLİ, Dokuz Eylül Üniversitesi, Türkiye, hunerliomur@ gmail.com \\ Orcid No: 0000-0002-4713-1900 \\ Üzeyir AYDIN, Dokuz Eylül Üniversitesi, Türkiye, uzeyir.aydin@deu.edu.tr \\ Orcid No: 0000-0003-2777-6450
}

\begin{abstract}
Öz: Önemli bir enerji kaynağı olan doğal gaz Türkiye'de neredeyse her ekonomik birim tarafindan kullanılmaktadır. Kullanım yerinin bu denli fazla oluşu ve giderdiği ihtiyaçların hayati bir nitelik taşıması da doğal gazı gelir ve fiyat esnekliği düşük bir mal durumuna getirmektedir. Ancak Türkiye'de oldukça az miktarda bulunan doğal gaz arzı, iç talebi karşılayamadığından ne yazı ki Türkiye bu enerji kaynağında dışarıya bağlıdır. İthalat kanalıyla ekonomik birimlerin edinebildiği doğal gaz gerek kendi piyasasının kendi dinamiğindeki, gerek uluslararası ekonomik, gerekse de politik risklerden kaynaklanan en kü̧̈ük bir etki ithalatçı durumdaki ülkeyi fazlasiyla olumsuz etkileyebilmektedir. Dolayısıyla doğal gaz kaynağına karşı böylesine savunmasız kalan bir ülke bu kaynağı da kendi dinamiklerinde oldukça tasarruflu ve etkin bir şekilde dağıtması ve kullanması gerekmektedir. Böyle bir durumda kit olan doğal gazın atıl ya da etkinsiz kullanımının mikro düzlemde ekonomik birimlere makro düzlemde ekonomiye yaratacağı yük oldukça fazla olacaktır. Bu kapsamda çalışmanın amacı ilgili ekonomik birimlere bu kaynağın ulaşttrılmasında sorumluluğu üstlenen dağıtım firmalarının ne kadar etkin (ya da etkinsiz) çalışstığın araştırmaktır. Bunun yanı sıra firmaların ayrı ayrı zaman kesitinde etkinlik iç dinamiklerinin de ayrıştırlarak açıklandı̆̆ toplam faktör verimliliğini de analiz etmek çalı̧̧manın bir diğer amacıdır. Bu amaçlara ulaşabilmek için yöneylem tabanlı Veri Zarflama Analizi (DEA/VZA) yaklaşımı kullanılmıştır. Enerji Piyasası Düzenleme Kurumundan derlenen 63 doğal gaz dağıtım firmasının 2013-2016 verileri analize dahil edilmişstir. CCR yöntemine göre etkin olan firma saylsl toplam firma saylsinın \%10'u kadarken BCC yönteminde bu oran \%14'tür. Diğer yandan etkin firmalar haricindeki firmaların ölçeğe göre artan getiride çalıştı̆̆ı ulaşılan bir başka bulgudur.
\end{abstract}

Anahtar Sözcükler: Etkinlik, Verimlilik, Doğal Gaz Dağıtımı, Enerji Ekonomisi, Veri Zarflama Analizi

Abstract: Natural gas is an important energy source that is used by nearly every economic unit in Turkey. The fact that the place of used is so high and the necessities that it fulfills carries a vital quality makes the natural gas a product with low income and price flexibility. However, relatively small amounts of natural gas in Turkey, unfortunately that Turkey meet the domestic demand is dependent on outside energy sources. Natural gas, which the economic units can acquire through the import channel, quite can affect the importing country which has the slightest impact on the dynamics of its own market, arising from both international economic and political risksTherefore, a country that is so vulnerable to natural gas resources should need to distribute and use this resource in a very efficient and efficient way in its own dynamics. In such a case, the burden of inert or ineffective use of scarce natural gas on the micro-economy and the macro-economy will be considerable. The aim of this study is to investigate how effective (or ineffective) the distribution companies that are in charge of delivering this resource to the relevant economic units. In addition, it is another objective of the study to analyze the total factor productivity in which the internal dynamics of the activity are separated and explained in a separate time section. In order to achieve these objectives, the Operational Data Envelopment Analysis (DEA / DEA) approach was used. The 2013-2016 data of 63 natural gas distribution companies compiled from the Energy Market Regulatory Authority were included in the analysis. While the number of firms effective according to CCR method is 10\% of the total number of firms, this ratio is 14\% in BCC method. On the other hand, it is another finding that firms other than active firms work on increasing returns to scale.

\section{Keywords: Efficiency, Productivity, Natural Gas Distribution, Energy Economy, Data Envelopment Analysis.}

\section{Giriş}

Günümüzde gerek hane halkları gerekse de firmalar açısından hayati öneme sahip olan başlıca doğal kaynaklardan olan doğal gazın geçmişi Türkiye için çokta eskiye dayanmamaktadır. Türkiye'de oldukça az miktarda bulunan bu doğal kaynak arzı iç talebi karşılayamadığından ne yazık ki Türkiye bu enerji kaynağında dışarıya bağlıdır. İthalat kanalı ile ekonomik birimlerin edinebildiği doğal gaz gerek kendi piyasalarının kendi dinamiğindeki, gerek uluslararası ekonomik, gerekse de politik risklerden kaynaklanan en küçük bir etki ithalatçı durumdaki ülkeyi fazlasıyla olumsuz etkileyebilmektedir. Yurtdısından ithal edilen bu doğal kaynak ülkemizde de neredeyse her ekonomik birim tarafından

\footnotetext{
${ }^{1}$ Yüksek lisans tezinden türetilmiştir.

Makale Gecmiși / Article History

Başvuru Tarihi / Date of Application : 30 Eylül / September 2019

Kabul Tarihi / Acceptance Date : 2 Kasım / November 2019
} 
kullanılmaktadır. Hane halkları için yoğunluklu olarak ısınma ve çeşitli temel gereksinimlerini karşılamak amacıyla kullanılan doğal gaz; firmalar için ise üretimlerini gerçekleştirebilmek için gerekli bir ara mal niteliği taşımaktadır. Son derece kıt bir şekilde Türkiye coğrafyasında bulunan bu doğal kaynağın ikamesi durumunda kullanılacak başka bir kaynağın bulunmaması da Türkiye'yi bu konuda yoksul kılan bir başka etmendir. Kullanım yerinin bu denli fazla oluşu ve giderdiği ihtiyaçların hayati bir nitelik taşıması da doğal gazı gelir ve fiyat esnekliği düşük bir mal durumuna getirmektedir. Bu denli zaruri bir nitelik taşıyan malın ya da hizmetin fiyatında meydana gelen değişmelere karşı koyabilmek pek mümkün olmadığından mikro anlamda ekonomik birimler makro anlamda ise ülke kırılgan bir niteliğe sahip olacaktır. Doğal gaz kaynağına karşı böylesine savunmasız kalan Türkiye bu kaynağı da kendi dinamiklerinde oldukça tasarruflu ve etkin bir şekilde kullanması gerekmektedir. Böyle bir durumda kıt olan doğal gazın atıl ya da aşırı anlamda niteliksiz kullanımının ekonomiye yaratacă̆ı yük oldukça fazla olacaktır.

Bu derece arzı az olan malın kullanımının rasyonel nitelik kazanabilmesi için kullanım etkinliğini ya da etkinsizliğini bilmek oldukça önem arz etmektedir. Hane halklarının kullanımının yanında çok daha yoğun olarak bu malı kullanan firmaların da bu etkinliğin bilincinde olması bir gerekliliktir. Pek tabii ithal edilen bu gazın ülke içine nasıl dağıtıldığı birincil anlamda etkinliğinin (etkinsizliğinin) başladığı ilk noktadır.

Doğal gazı ülke içinde dağıtım sorumluluğunu üstlenen firmaların kullandığ 1 ya da yaptığı çeşitli yatırımları ne kadar optimal ve dengeli bir şekilde nihai tüketicilerine ulaştırdı ̆̆ı, bu dağıtım firmalarının girdilerini ne derecede başarılı bir şekilde çıktıya dönüştürdüğü ile ilişkilidir. Çalışmada Türkiye'de faaliyet gösteren doğal gaz dağıtım firmalarının kullandığ1 üretim girdilerini, ne kadar rasyonel şekilde konut (hane) birimine ulaştırdığı analiz edilmek istenmiştir. Buradan hareketle 2013-2016 y1lları için bu piyasanın düzenleyici kurumu olan EPDK resmi sitesindeki sektör faaliyet raporlarından elde edilen verilerle 63 firma için yöneylem (matematiksel programlama) tabanlı VZA ile etkinlikverimlilik analizi yapılması amaçlanmıştır. Bununla beraber aynı zamanda bu firmaların ayrı ayrı zaman kesitinde etkinlik iç dinamiklerinin de ayıştırılarak açıklandığı analiz olan toplam faktör verimliliği analizi de gerçekleştirilmiştir.

Monopolistik bir özellik taşıyan bu dağıtım sektörünün alt bileşimlerini oluşturan bu firmaların dağıtımları ne kadar kaliteli ve dengeli şekilde yaptıklarını hesaplayarak gerek mikro iktisat gerekse de enerji iktisadı alanındaki bir boşluğu doldurmak çalışmanın literatüre önemli bir katkısını oluşturmaktadır.

\section{Doğal Monopol Teorileri}

Bir piyasada toplam çıktı miktarının birden çok firmanın üretmesi yerine tek firma tarafından üretilmesi daha karlı ya da daha az maliyetli bir duruma neden oluyorsa bu firmanın doğal monopol olduğunu söyleyebiliriz. Literatürdeki en önemli iki koşul toplamaltılık (subadditivity) ve sürdürülebilirlik (sustainability) özelliklerine sahip olunmasıdır. Daha az maliyetle üretme kavramı literatürde toplamaltılık (Subaddivity) ya da mutlak maliyet avantajı olarak çıkabilmektedir (Ölmezoğulları ve Çetin 2005, 37).

Geleneksel Monopol teorisine göre bir firmanın doğal monopol olabilmesi için ölçek ekonomisinden yararlanması gerekmektedir. Ölçek ekonomisi, artan üretim ölçeği karşısında üretim maliyetlerinin düşmesini yani azalan maliyet koşullarının oluşmasını ifade etmektedir.

Geleneksel Monopol teorisinin içinde ölçek ekonomilerinin oluşmasının altında yatan konu, toplam maliyetler içinde sabit maliyetlerin büyüklüğünün fazla olmasıdır. Özellikle enerji dağıtım, doğalgaz dağıtım, demiryolu ulaşım, elektrik üretimi ve telekomünikasyon sektörleri bu duruma örnek olarak gösterilebilmektedir. Bu saydığımız sektörlerde ayrıca fiziki sermayelerin bölünmezliği de sabit maliyetlerin fazlalaşmasında etkili olabilmektedir. Çünkü bölünmezliğin var olduğu sektörlerde rekabet edilebilir maliyetlerle üretim yapabilmek için veri teknoloji ile belirli büyüklükte bir üretim tesisi kurmak ya da üretim aracı kullanma zorunluluğu mevcuttur (Düzgün 2011, 11-13). Doğal monopol üreteceği malların niteliği temel ihtiyaç maddelerinden oluşması ve dönüşü olmayan yüksek maliyetleri gerektirmesi geleneksel teoriye göre doğal monopollerin taşıması gereken özelliklerden bazılarıdır (Ölmezoğulları ve Çetin 2005, 38).

Modern doğal monopol teorisine göre tek bir firma üretimi iki ya da daha çok firmanın gerçekleştirebileceğinden birim başına daha az maliyetle üretiyorsa ve piyasaya girişler doğal olarak cazip değil ve rekabet için başka firmaların piyasa içinde var olabilmesi olasılığı yoksa bu firma doğal monopol özelliği kazanabilmektedir. Geleneksel teoride maliyet avantajı (toplamaltılık) piyasada tek bir firmaya doğal monopol özelliğini kazandırırken modern teoride maliyet avantajı kuramını tek başına bir firmaya doğal monopol niteliği kazandıramamaktadır. Bununla birlikte piyasaya girişlerin doğal olarak cazip olmaması ve birden fazla firmanın varlığını bu piyasada sürdürebilmesinin mümkün olmaması gibi faktörler de doğal monopol niteliği kazanmak için gereklidir (Ölmezoğulları ve Çetin 2005).

Modern Doğal Monopol teorisinde ayrıca üzerinde durulan bir başka faktör de teknolojik yeniliklerdir. Modern teoriye göre teknolojik yeniliklerin varoluşu monopol yapıyı tehdit etmektedir. Çünkü teknolojik yenilikler doğal monopollerin maliyet ve ölçek yapılarını değiştirirken bununla birlikte bazı sektörlerin tamamen doğal monopol olmasını engelleyerek rekabetçi bir duruma getirebilmektedir. Çünkü teknolojik yenilikler var oldukça monopol niteliği taşıyan ürünlerin karşısında ikame mallar meydana gelmekte ve bunun sonucu olarak monopol yapısı kaybedilmektedir. Fakat geçmişi A.B.D.'de yaklaşık 100 yıl kadar öncesine dayanan bu yapılanmanın belli teknoloji üretme kapasitesi yüksek olan sektörlerde anti-tröst anlaşmaların uygulanması rafa kaldırılmasına neden olmuştur. Bunun nedeni teknoloji ve eşsiz iş gücü üretecek olan bu sektörlerin doğal monopol olarak var olması küresel ekonomik entegrasyonu bu denli savunan bir ülkede dahi mevcut olagelmiştir (Joskow 2006, 1-2).

Geleneksel Doğal Monopol teorisinde ölçek ekonomisinin maliyetler üzerindeki etkisi teknoloji veri iken incelenmektedir. Hâlbuki gerçekte durum pekte öyle değildir. Çünkü zaman içerisinde teknolojide büyük değişimler 
meydana gelmekte ve bu değişimler de monopolün maliyet yapısını önemli ölçüde etkilemektedir. Gelişen teknoloji ile firmaların minimum etkin ölçekleri küçülmekte, yatırım ve hatta inisyal maliyetlerini azaltmakta ve yatırımların gerçekleşme süresini kısaltmaktadır. Bu durum tarihte çeşitli sektörlerde gerçekleşmiş ve var olmaya da devam etmektedir. Örneğin daha önce monopol özelliği taşıyan mobil telefon sektöründe gelişen teknoloji ile 1996 ve 2000 'li yıllarda piyasaya yeni giren firmaların pazar payını genişleterek piyasanın doğal monopol yapısını oldukça aşındırmıştır. Akabinde cep telefonu sektöründe ikame malların çeşitliliği sonucu sektör monopol yapısını oldukça kaybetmiş ve rekabetçi bir duruma gelmeye başlamıştır. Hatta bu teknolojik gelişme sadece cep telefonu sektörünün monopol yapısını değil kablolu telefonların dahi sektörel yapısını tehdit eder duruma gelmiştir. Bir başka monopol bariyerlerinin yıkıldığı sektör de elektrik dağıtım sektörü olmuştur. Bu sektördeki teknolojik gelişmeler santrallerin minimum etkin ölçeğini düşürmüş ve yatırım maliyetlerini azaltmıştır. Bunun sonucunda da sektör birçok gelişmekte olan ekonomiler ve geçiş ekonomilerinde rekabetçi duruma gelmiştir. Benzer etki daha sonra doğal gaz dağıtım sektöründe de görülmeye başlanmıştır. Akabinde dağıtım daha küçük firmalarca yapılmaya başlanmıştır. Şekil 1-4'den de görüldüğü üzere Amerika'da elektrik dağıtım şirketlerinin yıllar itibariyle büyüklükleri ve yatırım maliyetlerinin düşüşü gösterilmektedir (Kessides 2004, 38-40).

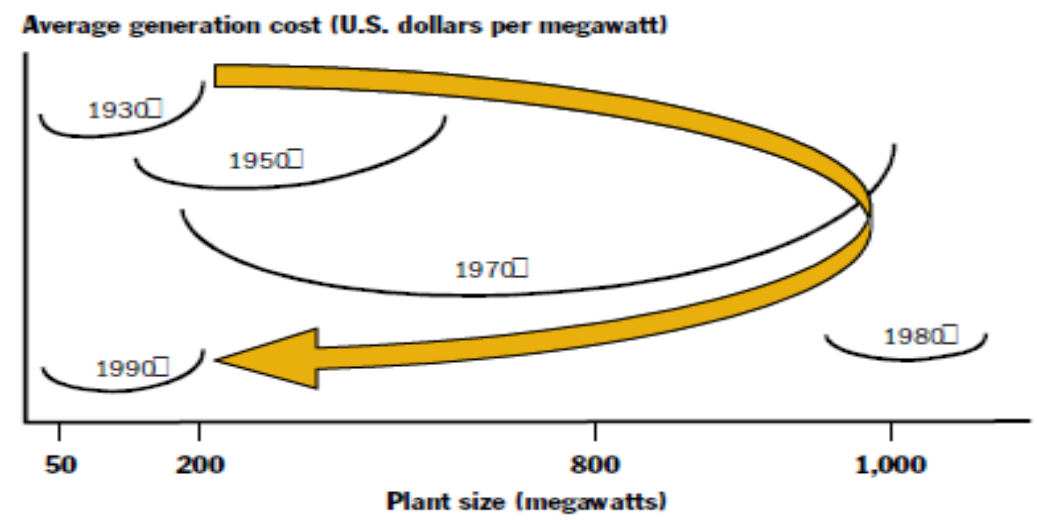

Şekil 1. Amerika’da Zamana Göre Büyüklüğü Ve Maliyetleri Düşen Elektrik Dağıtım Şirketleri

Kaynak: Kessides 2004, 39

Modern Doğal Monopol teorisine göre; tek ürünlü firma çerçevesinde azalan maliyetlerin var olması kuralı için zorunluluk yoktur. Yani piyasada artan maliyetler varken de doğal monopoller oluşabilmektedir. Çok ürünlü firma modelinde de ölçek ekonomilerine bağlı kalmadan maliyet avantajlarına bağlı olarak doğal monopoller oluşabilir. Bu avantajlar da alan ekonomilerinin varlığ 1 ile ilişkilidir.

Doğal Monopolün bir piyasada gerçekleşmesi ancak piyasaya devlet müdahalesinin olmaması durumunda görülebilmektedir. Böyle bir durumda ise tek başına firma ürettiği mala çok yüksek fiyat biçerken oldukça düşük bir üretim miktarı belirlemektedir. Devlet böyle bir durumda piyasaya firma girişlerini teşvik etse de birden çok firmaca üretim gerçekleşeceğinden üretim maliyetleri yükselecek bu kez de piyasada ciddi refah kayıpları meydana gelecektir.

Doğal Monopol şartları piyasada mevcutken hiçbir firma fiyat kabullenici olmayacaktır. Piyasada en küçük etkin ölçek oluşursa ve bahsettiğimiz diğer doğal monopol şartları da oluşursa $\mathrm{P} \geq \mathrm{LAC}_{\min }$ durumu oluşacak ve monopol gücü oldukça şiddetlenecektir. Eğer bahsettiğimiz bu firma fiyatlamasını $\mathrm{P}=\mathrm{LAC}_{\min }$ olarak yapmak istediğinde firma zaten fiyatları etkileyebileceğinin farkına varacaktır.

Yukarıda da bahsedildiği üzere doğal monopolün oluşması birden çok faktöre bağlıdır. Tek ürün üretirken ölçek ekonomisinin varlığı ve toplamaltılık ve birden çok ürün üretiminde bunlara ek olarak kapsam ekonomilerinin varlığını da eklemek gerekmektedir. Ancak günümüzde küreselleşen dünya ekonomisi sonucunda doğal monopolün varlığı da oldukça sınırlanmakta ve uluslararası rekabetin varlığı ile devlet özelleştirmeleri sonucu oldukça azalmaktadır. Ayrıca hükümetlerce yine uygulanan tavan fiyatı gibi tüketici yanlı politikalar da bu yapının oluşmasını engelleyen bir diğer faktörlerdendir. Doğal Monopolün son örnekleri de bahsettiğimiz gibi hizmet sektörlerindedir. Yani doğal monopol günümüz şartlarında daha çok hizmet iktisadı dalında yoğunluk gösteren bir yapılanma olarak karşımıza çıkmaktadır (Akal 2015, 440-442).

\section{Etkinlik ve Verimlilik}

Verimlilik, en basit anlamda çıktının girdiye oranı olarak ifade edilmektedir. Buradan hareketle görülmektedir ki verimlilik kavramı göreli bir kavram değildir. Bu nedenle incelenen karar verici birimlerin verimliliklerini birbirinden bağımsı̈ ölçme imkanı vardır (Tarım, 2001: 11).

Üretim girdilerin çıktılara dönüştürülme sürecidir. Bu sürecin etkin olabilmesi zaman boyutu dikkate alınmadığında mevcut teknoloji çerçevesinde, belli bir girdi bileşimin kullanılarak maksimum çıktının elde edilmesine veya belli bir çıktı bileşiminin en az girdi kullanılarak üretilmesine bağlıdır. Teknik etkinlik, karar biriminin girdi bileşiminin en verimli 
şekilde kullanarak mümkün olan maksimum çıktıyı üretme başarısıdır. Yani teknik etkin olan karar birimleri üretim sınırı üzerinde yer alması gerekmektedir. Üretim sınırının altında kalan karar birimlerinin göreli olarak kaynaklarını israf ettikleri söylenebilir (Tarım 2001, 15-16).

\subsection{Veri Zarflama Analizi}

Veri zarflama analizi, benzer girdiler kullanarak benzer çıktılar üreten karar birimlerinin (üretim birimlerinin) etkinliklerini ölçmeye yarayan parametrik olmayan bir yöntemdir. Kısaca VZA istatistiksel değil deterministik bir yöntemdir. Çünkü girdi ve çıktı arasındaki herhangi bir fonksiyonel ilişki bulunmamaktadır (Dinçer 2011, 37). VZA'da karar birimleri, istatistiksel yöntemlerde olduğu gibi ortalama verimlilikle değil, en verimli birime göre kıyaslama yapılarak gerçekleştirilmektedir. Bu özelliğinden hareketle VZA bir uç sınır tekniği olarak adlandırılabilmektedir.

VZA durağan (statik) bir yöntemdir. Yani analizde hesaplanan etkinlik skorları karar birimlerinin sadece ele alınan dönemdeki geçerli etkinlik skorlarıdır (Yücel 2017, 1). VZA'da amaç, söz konusu sınırı "referans” kabul edip etkin olmayan karar birimlerinin bu sınıra olan uzaklıklarını (veya etkinlik düzeylerini) ölçmek ve bu etkinlik sınırını kullanarak etkin olmayan karar birimlerine model almaları gereken karar birimleri önererek etkin hale gelmeleri için yapmaları gereken değişiklikleri göstermektedir. Ayrıca çoklu girdi ve çıktılı analize uygun bu yöntemde baştan belirli bir fonksiyon kalıbı şart koşulmamaktadır (Aydın ve Kök 2013, 9).

VZA'nın çıkış noktası, Farrell'in ağırlıklı çıktıları ağırlıklı girdilere oranlayarak performans ölçümü yapan "toplam faktör verimliliği” yaklaşımıdır. VZA'nın ortaya konulan bu ilk modeli kesirli bir yapıya sahiptir. Ancak daha sonra doğrusal programlama yöntemlerinin çalışmalara dâhil edilmesiyle VZA modelleri doğrusal programlamaya konu olmaya başlamıştır (Yücel 2017, 1-2).

Farrel'in teknik etkinlik üzerine yaptığ1 bu çalışmadan sonra Edwardo Rhodes 1978'de Cornegie Mellon Üniversitesinde çalışmalarına başlamıştır. Bu çalışmada Rhodes örgün eğitim programına dâhil olan ve dâhil olmayan okul gruplarının performanslarını incelemeye başlamıştır. Çalışmada 70 karar biriminin fiyatları yok sayarak çoklu girdi ve çıktılı modelle tahmin etme isteği CCR (Charnes, Cooper, Rhodes) VZA modelini ortaya çıkarmıştır. Ve bu çalışma ilk olarak Journal of Operations Research dergisinde 1978'de yayımlamıştır (Charnes vd. 1994). Bu model ölçeğe göre sabit getiri varsayımı altında uygulanmaktadır (Kurtlar ve Kartal 2004, 52-53).

CCR yöntemi olarak ortaya atılan bu model ölçeğe göre sabit getiriyi esas almaktadır. Daha sonra ise ölçeğe göre değişken getiriyi ana plana koyan ve Banker, Charnes, Cooper tarafından geliştirilen BCC modeli geliştirilmiştir. Bu model CCR modeline konvekslik kısıtının eklenmesi ile türetilen bir yöntemdir. Her iki yöntemin de girdi ve çıktı yönelimli iki farklı opsiyonu bulunmaktadır. Girdi yönelimli (input oriented) modelde var olan belli bir çıktıyı elimizdeki girdileri minimum hale getirirken üretmeyi, çıktı yönelimli (output oriented) model ise girdilerimizi değiştirmeden üreteceğimiz çıktıları nasıl maksimum hale getireceğimizi hedeflemektedir.

Veri zarflama analizinin bazı güçlü yanlarına değinecek olursak (Karahan ve Özgür 2011, 120-122);

- VZA birden çok girdiyi ve çıktıyı kullanabilecek niteliğe sahiptir.

- Girdi ve çıktılar farklı birimlerde olabilirler.

- Parametrik yöntemlerdeki belli bir üretim sistematiği gereksinimine VZA'da ihtiyaç yoktur.

- VZA'da karar birimleri göreli olarak tam etkinliğe sahip olanlarla kıyaslanır.

- Homojen nitelikteki karar birimlerinin etkinliklerini birbirleri ile kıyaslama yapmasını sağlar.

Bunun yanında veri zarflama analizinin bazı zayıf yönleri de mevcuttur.

- Ölçüm hatalarına karşı duyarlılık yüksektir.

- İstatistiksel hipotez testlerinin uygulanması zordur.

- Büyük boyutlu problemlerin VZA ile çözümü zaman alıcı olabilmektedir.

- VZA'da rassal hatalara yer olmadığından, ölçme yöntemleri ve verilerde var olan gürültü ayıklanamaz bundan dolayı da verilerle ilgili problemler sonuçlara oldukça yansıyabilmektedir.

- VZA genel olarak fiziksel girdi ve çıktı ölçütleri ile test edildiğinden sadece teknik anlamda girdi ve çıktı verimliliğini verebilmektedir.

- Yapılan modellemelerde dışsallıklara da yer verilmesi daha gerçekçi sonuçların alınmasını sağlayacaktır.

- Gözlemci karar birimlerini seçerken benzer niteliklere sahip karar birimlerini ele almalıdır. Aksi takdirde sonuçlar gerçekçi olamamaktadır.

VZA analizi ile gerçekleştirebileceğimiz amaçlar (Andersen ve Petersen 1993, 1262);

- Karar birimlerinin girdi-çıktı eğilime göre yapılan analizi sonucunda göreli etkinsizliğinin ve kaynaklarının belirlenmesi,

- Politika önerisi bazında firmalara yönetsel ve süreçsel etkinsizliklerinin açıklanarak etkin hale gelen KVB'lere dönüşmesi,

- Atıl ya da eksik kaynakları daha etkin kullanmak için önerilerde bulunulması,

- KVB'lere etkin girdi ve çıktı kullanma bileşimleri sunabilme,

- Etkin olmayan KVB'lere rol model olarak en etkin KVB'leri ağırlıkları ile sunabilme,

- Firmalara maliyet avantajı ve çıktı maksimizasyonu hakkında öneriler sunup karşılaştırabilme, 
VZA'da bir karar biriminin girdisini minimum düzeye getirme ve çıktısını maksimum seviyeye getirme amacı bulunmakta ve bu miktarlar ile girdi ve çıktılarını ağırlıklandırmaktadır. Fakat çalışmada karar birimi sayısı değişmezken girdi ve çıktının artırılması modellerde serbestlik problemine neden olabilmektedir. Bunun nedeni ise karar birimi sayısı düşük bir miktarda iken girdisini minimum, çıktısını ise maksimum seviyede tutma eylemini sürdürmek isteyen karar biriminin kullandığı ve ürettiği bu değişkenlerin miktarına bağlı başka karar birimi bulunamadığından (başta KVB'yi sabit kabul etmiştik) eskiye nazaran birçok KVB kendiliğinden etkin hale gelecektir. Bu nedenden ötürü bu problemi baştan bertaraf edebilmek için örneklem miktarının girdi ve çıktı sayısından en az üç kat fazla olması gerektiği kısıtı oluşturulmuştur. Ancak mega büyüklükte bir örneklemle çalışırken de seçilecek iki girdili, tek çıktılı bir yöntem de çalışmanın ayrıştırma gücünü olumsuz etkileyecektir (Demirci 2018, 60-61).

\subsection{Malmquist TFV Endeksi}

Toplam faktör verimliliği elde edilen çıktıların derneşik hale getirilmiş (aggregated) girdilere olan oranı olarak ifade edebiliriz. Malmquist Toplam Faktör Verimliliği endeksi var olan iki gözlemin toplam faktör verimliliğindeki değişmeyi ortak bir teknolojiye olan uzaklıkların oranı olarak ölçmektedir. Caves ve diğerleri tarafından 1982'de ortaya çıkarılan bu endekse, uzaklık fonksiyonlarının yardımı ile endeks kurma fikrini ilk ortaya atan Sten Malmquist'e ithafen Malmquist ismi verilmiştir. Yukarıda da bahsedildiği gibi endeks "Uzaklık Fonksiyonları" ile çalışmaktadır. Uzaklık fonksiyonları birden çok girdi ve çıktıdan oluşan üretim teknolojilerini maliyet minimizasyonu ve kar maksimizasyonu gibi hedefleri tanımlamaksızın açıklamaktadır. Uzaklık fonksiyonu $d(x, y)=\min \{\delta:(y / \delta) \in S\}$ olarak tanımlanır. Uzaklık fonksiyonu $d(x, y)$ 'nin alacağı değerler, $y$ vektörü $S$ sınırı (üretim sınırı) üzerinde ise 1.0; $y$ vektörü $S$ içindeki teknik etkin olmayan bir noktayı tanımlıyorsa $>1.0$; ve $y$ vektörü $S$ dışındaki mümkün olmayan bir noktayı tanımlıyorsa $<1.0$ 'dir $($ Cingi ve Tarim 2001, 10).

Toplam Faktör Verimliliği (TFV) endeksi karar birimlerinin üretkenliğini zaman boyutunu da dikkate alarak ölçmektedir. Bu endeksteki değer karar birimi için toplam faktör verimliliğindeki değişme olarak yorumlanmakta ve eğer bu değer 1'den yüksekse toplam faktör verimliliğinde bir artışa 1'den düşük ise bir azalışa işaret etmektedir. Toplam faktör verimliliğinin teknik etkinlikteki değişme ve teknolojideki değişme olarak iki farklı alt bileşeni bulunmaktadır. Bu iki alt bileşen ile toplam faktör verimliliğinin etkileşimi büyük bir önem taşımakta ve uygulama bölümünde de bu duruma sık sık atıfta bulunulmaktadır. Bunun dışında ayrıca teknik etkinliğin de iki alt bileşeni bulunmaktadır. Bunlar pür ekonomik etkinlik ve ölçek etkinliğidir. Tüm bu yorumlardan hareketle;

$\Delta$ Teknik Etkinlik $=\Delta($ Pür Ekonomik Etkinlik $) \times \Delta($ Ölçek Etkinliği $)$

$\mathrm{TFP}=\Delta($ Teknik Etkinlik $) \times \Delta($ Teknoloji $)$

Pür Ekonomik Etkinlik yönetimsel anlamdaki değişimi, ölçek etkinliği ise karar birimlerinin optimal ölçekte çalışıp çalışmadığını göstermektedir. Teknolojideki değişim ise aynı girdi ile çıktı miktarındaki değişimin yönünü göstermektedir (Karahan ve Özgür 2009, 108). Buradan hareketle öz olarak çıktı birden çok girdi ile ilişkili ise toplam faktör verimliliği olarak adlandırabilmek mümkünken çıktı tek girdi ile ilişkili olduğunda kısmi faktör verimliliği olarak isimlendirilmektedir (Öncel ve Şimşek 2011, 89). Bu ilişkilerden hareketle pür ekonomik etkinlik BCC'ye göre etkinlik değişimi tanımı ile, teknik etkinliği ise (pür ekonomik etkinliğin ölçek etkinliği ile genişletilmiş bir varyasyonu) CCR etkinlik değişimi tanımı ile bir anlamda uyuşmaktadır

Malmquist toplam faktör verimliliğinin bir diğer özelliği de endeksin panel veri setine uygunluluğudur. Çünkü ancak böyle bir durumda üretkenliğin zaman boyutu ile paralel olarak gelişimini hesaplamak ve alt bileşenlerine inerek nedenlerini saptamak mümkündür (Benli 2012, 371).

\section{Ampirik Literatür Taraması}

Dağıtım şirketlerinin etkinliklerinin ölçümü ile ilgili çalışmalar daha çok Elektrik ve su dağıtım sektöründe gerçekleşmiş son yıllarda doğalgaz dağıtım sektöründe de benzer çalışmalar yapılmaya başlanmıştır. Özellikle enerji sektöründe dışa bağımlı (net enerji ithalatçısı) olan ülkelerde bu çalışmalar doğalgaz dağıtım sektörüne daha çok uygulanmaya başlanmış ve bu şekilde ülkelere hem kendi içlerinde firmaların daha optimum faaliyette çalışmasını sağlayacak politika önerileri sunulmuş hem de enerji ithalatının azaltılması için yol gösterici olmuştur.

Marques vd.'nin yaptığı çalışmada frontier metodu ile 2008-2009 yılları arasında farklı coğrafyada faaliyet gösteren 11 Portekiz doğalgaz dağıtım şirketlerinin ölçeğe göre değişken getiride etkinlikleri ölçülmüştür. Çalışmada tüketici sayısı, gaz dağıtım miktarı ve network uzunluğu çıktı olarak seçilirken fiyat tabanı düzenlemesi olan OPEX değişkeni girdi olarak seçilmiştir. Yani uygulanan regülasyonun çıktı üzerine olan etkisi araştırılmıştır. Çalışmadaki karar birimleri arasında boyutsal farklılıklar bulunduğundan çalışma VRS-DEA baz alınarak yapılmıştır. Oluşturulan dört farklı modele göre etkinlikler fazlaca değişirken genel olarak neredeyse tüm karar birimlerinin optimum ölçeğin altında çalışıyor olarak bulunmuştur ki bu da sektörün henüz doygunluğa erişmediğine işaret olarak gösterilmektedir (Marques vd. 2011, 17-25).

Bir başka çalışmada ise İtalya'da faaliyet gösteren 32 firmanın etkinlikleri ölçülmektedir. Storto çalışmasında çalışan maliyetleri ve indirekt faaliyet maliyetlerini girdi olarak seçerken, ağ uzunluğu, belediye sayısı, tüketici sayısı, doğalgaz hacmi ve mali devir hızı çıktı olarak belirlemiştir. Tanımlayıcı istatistik sonuçlarına göre CRS yerine VRS metodunun kullanılmasını daha uygun bulunmuş ve bunun sonucunda da İtalya'daki doğalgaz dağıtım şirketlerinin geniş ölçekli olmasının etkinsizliğe neden olduğunu sonucuna varılmıştır. Ayrıca çalışmada firmaların çoğunun (20 karar biriminin) ölçeğe göre azalan ölçekte çalıştı̆ğ tespit edilmiştir (Storto 2014, 1972-1978). 
Yine İtalya'daki doğalgaz dağıtım şirketleri üzerinde yapılan bir başka araştırmaya göre; İtalya'da faaliyet gösteren doğalgaz dağıtım şirketlerinin etkinlikleri ölçülmüş. Firmaların büyüklüklerinin birbirinden çok farklı olduğuna ve sektörün daha çok monopolleştiği sonuçlarına varılmıştır. Böyle bir faktördeki büyüklük farklılaşması neticesinde BCC yönteminin daha çok tercih edilesi olduğunu da göstemektedir. Çalışmada ortalama faaliyet ve sermaye harcamaları yani maaliyetler girdi olarak kullanılırken çıktılar ise abone sayısı, paylaşılan hacim ve hat uzunluğu olarak seçilmiştir (Erbetta ve Rappuoli 2003, 2-19).

Slovenya'da Zorić, Hrovatin ve Scarsi tarafından yapılan bir başka çalışmada ise Sloven gaz dağıtım şirketleri ile Birleşik Krallık ve Hollanda'daki gaz dağıtım şirketleri arasında etkinlik kıyaslamaları yapılmıştır. 42 karar birimini kapsayan çalışmada girdi ve çıktılar aralarında değişmekle birlikte faaliyet harcamaları, abone sayısı, satış miktarı, maksimum talep ve ağ uzunluğu değişkenleri kullanılmıştır. Ayrıca çalışmada doğalgaz dağıtım firmalarının etkinliklerini ölçerken kullanılabilecek kılavuz niteliği taşıyan girdi ve çıktı değişkenleri gösterilmiştir.

Tablo 1. Sıklıkla Kullanılan Değişkenler

\begin{tabular}{|l|l|}
\hline \multicolumn{1}{|c|}{ Girdi } & \multicolumn{1}{c|}{ Çlktl } \\
\hline Calışan sayısı & Abone sayısı (Konut) \\
\hline Hat uzunluğu $(\mathrm{km})$ & Toplam Paylaşılan Hacim $\left(\mathrm{m}^{3}\right)$ \\
\hline Taşıma kapasitesi & Konut satış hacmi $(\mathrm{m} 3)$ \\
\hline Faaliyet harcamaları & Yerleşik olmayan satı̧ hacmi $\left(\mathrm{m}^{3}\right)$ \\
\hline Toplam harcamalar & Hizmet alanı $\left(\mathrm{km}^{2}\right)$ \\
\hline Kontrol edilebilir faaliyet harcamaları & Maksimum talep \\
\hline & Ăg uzunluğu \\
\hline
\end{tabular}

Kaynak: Zorić vd. 2009, 120

Yapılan bu analizler sonucunda Sloven doğalgaz dağıtım şirketlerinin Birleşik Krallık ve Hollanda'daki dağıtım şirketlerine göre verimlilikleri düşük bulunmuştur. Bu durumun arkasında yatan gerekçe Sloven doğalgaz endüstrisindeki düzensizliklerdir. Birleşik Krallıkta faaliyet gösteren dağıtım şirketleri ölçeğe göre azalan getiride çalışırken, Hollanda'dakiler optimal ölçeğe yakın çalışmakta olmasına rağmen Slovenya'daki türdeşlerin ölçeğe göre artan getiride çalışmakta olduğu tespit edilmiştir. Ve ayrıca Sloven şirketlerin etkinliği de diğer iki ülkedekilere oranla oldukça düşüktür. Uygulanan bazı fiyat düzenlemeleri (fiyat tavanı) tarafından bu etkinsizliğin düşürülmeye çalıştığı da çalışmada belirtilmiştir (Zorić vd. 2009, 113-123).

Hollas vd (2002) ABD’de 33 doğalgaz firmasının, Carrington vd. (2002) Avustralya'da 24, Kim ve Lee (1995) Güney Kore'de, Haney ve Pollitt (2009) uluslararası 40 ülkedeki doğalgaz etkinliğini ve Hawdon (2003) uluslararası 33 ülkenin teknik etkinliğini araştırmıştır (Yanes vd. 2013).

\section{Uygulama Verileri ve Karar Verici Birimler (Firmalar)}

Toplamda ülkemizin yedi coğrafik bölgesinde faaliyet gösteren 63 doğal gaz dağıtım firmasından oluşturulan örneklemde 2013-2016 yılları arasındaki üç girdisi ve tek çıktısı ile toplamda 252 gözlem ile çalışma yapıllmıştır. Çalışma öncesinde toplanan verilerde toplamda 69 olan firma sayısı belirtilen yıllar içerisinde bazı verilerine ulaşılamayan beş ve devrolan bir firmanın analizden çıkartılmasıyla 63'e gerilemiştir. 63 adet doğal gaz dağıtım firmasının EPDK sitesindeki yıllara göre sıralanmış faaliyet raporundan toplanan veriler çalışmaya dâhil edilmiştir. Tüm değişkenler logaritmik olarak ifade edilmektedir. İncelenen literatürden hareketle çalışmanın değişkenleri ve değişkenlere ilişkin tanımlayıcı istatistikler aşağıdaki tablolarda verilmiştir.

Tablo 2. Uygulama Değişkenleri

\begin{tabular}{|c|c|c|}
\hline & Değişkenler & Açıklama \\
\hline \multirow{3}{*}{ Girdiler } & Kadrolu personel sayısı (birey) (lkps) & $\begin{array}{l}\text { Müteahhit elemanı ve taşeron fima iş̧̧ sayısı arızilik teşkil edebileceğinden ötürü çalışma dışı } \\
\text { bırakılmıştır. }\end{array}$ \\
\hline & $\begin{array}{l}\text { Polietilen boru hattı uzunluğu (metre) } \\
\text { (lnpbh) }\end{array}$ & \multirow[t]{2}{*}{$\begin{array}{l}\text { Herhangi bir derneşikleştirme ve ayrıştırmaya gerek kalmaksızın firma bazında elde edilen } \\
\text { veriler kullanılmıştır. }\end{array}$} \\
\hline & $\begin{array}{l}\text { Çelik boru hattı uzunluğu (metre) } \\
\text { (lncbh) }\end{array}$ & \\
\hline Çıktı & Konut abone sayısı (hane adet) (kas) & $\begin{array}{l}\text { Aynı doğal gaz dağııım şirketinin birden çok şehirde faaliyet göstermesinden dolayı raporda } \\
\text { şehirler bazında açılanan konut abone sayısı derneşik hale getirilerek tek bir firma olarak ifade } \\
\text { edilmiş ve çalışmaya bu şekilde dâhil edilmiştir. }\end{array}$ \\
\hline
\end{tabular}

Tablo 3. Uygulama Değişkenlerine Ait Tanımlayıcı İstatistikler

\begin{tabular}{|c|c|c|c|c|}
\hline & $\begin{array}{l}\text { Çelik Boru Hattı Uzunluğu } \\
\text { (lncbh) }\end{array}$ & $\begin{array}{l}\text { Polietilen Boru Hatt1 } \\
\text { Uzunluğu (lnpbh) }\end{array}$ & $\begin{array}{c}\text { Kadrolu Personel Sayıs1 } \\
\text { (lkps) }\end{array}$ & $\begin{array}{c}\text { Konut Abone Sayis1 } \\
\text { (kas) }\end{array}$ \\
\hline Ortalama & 156.694 & 1.054 .013 & 113 & 162.836 \\
\hline Standart Hata & 17.473 & 125.850 & 17 & 31.317 \\
\hline Ortanca & 75.713 & 532.743 & 58 & 70.304 \\
\hline Kip & 8.598 & -- & 47 & 193.268 \\
\hline Standart Sapma & 277.379 & 1.997 .811 & 272 & 497.138 \\
\hline Örnek Varyans & 76.939 .277 .278 & 3.991 .248 .575 .546 & 74.197 & 247.146 .253 .327 \\
\hline Basıklık & 21,207 & 36,393 & 46,101 & 55,942 \\
\hline Çarpıklık & 4,458 & 5,690 & 6,647 & 7,205 \\
\hline
\end{tabular}


Hünerli, Ö., C., Aydın, Ü. / Journal of Yasar University, 2019, 14 (Special Issue), 133-146

\begin{tabular}{|l|l|l|l|l|}
\hline Aralık & 1.821 .963 & 15.452 .434 & 2.124 & 4.448 .269 \\
\hline En Büyük & 8.598 & 46.607 & 15 & 498 \\
\hline En Küçük & 1.830 .561 & 15.499 .041 & 2.139 & 4.448 .767 \\
\hline Toplam & 39.486 .783 & 265.611 .171 & 28.485 & 41.034 .738 \\
\hline Say & 252 & 252 & 252 & 252 \\
\hline Güvenirlik Düzeyi(95,0\%) & 34.413 & 247.857 & 34 & 61.677 \\
\hline
\end{tabular}

\section{6. Çalışmanın Amacı}

Çalışmada amaç genel anlamda enerji ithalatçısı olan ülkemizin doğal kaynak açısından bol olan ülkelerden satın aldığı kaynaklardan biri olan doğal gazın ülke içi dağıtımının ne kadar etkin olduğunun belirlenmesidir. İktisat teorisinde kıt kaynakların en etkin nasıl dağıtıldığı ve ne derecede etkin olduğu ana gaye olmasından hareketle ülkemiz için kıt olan bu kaynağın en optimal şekilde nasıl dağıtıldığı ve dağıtılması gerektiği çalışmamızın öncelikli hedeflerindendir. Bu kapsamda hem mikro iktisat hem işletme iktisadı hem de enerji iktisadı literatürüne faydalı olmak amacı bir diğer hedeftir.

İktisat ve İşletme literatüründeki optimalizite nosyonundan hareketle doğal gaz sektöründe faaliyet gösteren firmalara görece olarak seçilen örneklem içindeki durumunu göstermek ve nasıl daha iyi olabilecekleri amacı da güdülmektedir. $\mathrm{Bu}$ amaçların tümünden hareketle yöneylem literatüründe yer alan Veri zarflama analizinden yararlanılmıştır.

Veri Zarflama Analizi yöntemi adı altında önce ölçeğe göre sabit getirili model olan CCR, daha sonra da ölçeğe göre değişken getirili model olan BCC kullanılarak yapılmıştır. Daha sonra VZA yöntemine göre firmaların farklı fazlardaki nitelik değişimleri sonucu Malmquist Toplam Faktör Verimliliği değerlerine ulaşılmıştır. Çalışmada winfordeap isimli uygulama kullanılarak etkinlik skorları elde edilmiştir.

\section{VZA (DEA) Uygulama Sonuçları}

Uygulamada dağıtım şirketlerinin çıktıları üzerinde kontrol gücünün de yüksek olmayışından analiz girdi yönelimli (input oriented) olarak tasarlanmıştır. Önce ölçeğe göre sabit getirili CRS modeli ardından ölçeğe göre değişken getirili BCC modeli ve ölçek etkinliğine göre etkinlik skorları elde edilmiştir.

\subsection{Etkinlik Skorlart}

Skorlar Tablo 4'deki gibidir.

Tablo 4. Firma Etkinlik Skorları ve Girdi Aylaklıkları

\begin{tabular}{|c|c|c|c|c|c|c|c|c|c|c|c|c|c|c|c|}
\hline & \multicolumn{3}{|c|}{$\begin{array}{c}\text { Etkinlik } \\
\text { Değerleri }\end{array}$} & \multirow{2}{*}{$\begin{array}{l}\text { Ölçę̆ } \\
\text { Göre } \\
\text { Getiri }\end{array}$} & \multicolumn{3}{|c|}{\begin{tabular}{|c|} 
BCC'ye Göre \\
Girdi Aylakllklart
\end{tabular}} & \multirow[b]{2}{*}{ Firmalar } & \multicolumn{3}{|c|}{$\begin{array}{c}\text { Etkinlik } \\
\text { Değerleri }\end{array}$} & \multirow{2}{*}{$\begin{array}{l}\text { Ölçěge } \\
\text { Göre } \\
\text { Getiri }\end{array}$} & \multicolumn{3}{|c|}{\begin{tabular}{|c|} 
BCC'ye Göre \\
Girdi Aylaklıklart
\end{tabular}} \\
\hline Firmalar & $C R S$ & $B C C$ & Ölçek & & lncbh & $\operatorname{lnpbh}$ & lkps & & $C R S$ & $B C C$ & Ölçek & & $\ln c b h$ & $\operatorname{lnpbh}$ & lkps \\
\hline 1. Agdaş Adapazarl gaz & 0.098 & 0.608 & 0.161 & Irs & & & & 33. Diyarbakar doğal gaz & 0.011 & 0.597 & 0.018 & Irs & & & \\
\hline 2. Akmercan Batıkar doğal g. & 0.007 & 0.700 & 0.010 & Irs & & & & 34. Enerya Aksaray doğal gaz & 0.010 & 0.688 & 0.015 & Irs & & & \\
\hline 3. Akmercan Delta doğal gaz & 0.935 & 0.968 & 0.966 & Irs & & & 1474 & 35. Enerya Antalya doğal gaz & 0.811 & 0.846 & 0.958 & Irs & & & 19482 \\
\hline 4. Akmercan Gepa doğal gaz & 0.866 & 0.942 & 0.919 & Irs & & & & 36. Enerya Aydın doğal gaz & 0.854 & 0.909 & 0.940 & Irs & & & \\
\hline 5. Akmercangaz doğal gaz & 0.097 & 0.651 & 0.149 & Irs & & & & 37. Enerya Denizli doğal gaz & 0.982 & 0.986 & 0.996 & Irs & 42869 & & \\
\hline 6. Aksa Afyon doğal gaz & 0.099 & 0.661 & 0.150 & Irs & & & & 38. Enerya Ereğli doğal gaz & 1.000 & 1.000 & 1.000 & - & & & \\
\hline 7. Aksa Balıkesir doğal gaz & 0.104 & 0.668 & 0.155 & Irs & & & & 39. Enerya Erzincan doğal gaz & 0.096 & 0.581 & 0.166 & Irs & & & \\
\hline 8. Aksa Bandirma doğal gaz & 0.103 & 0.597 & 0.172 & Irs & 39630 & & & 40. Enerya Kapadokya doğal ga & 0.103 & 0.641 & 0.160 & Irs & & & \\
\hline 9. Aksa Bilecik Bolu doğal g. & 0.979 & 0.982 & 0.996 & Irs & 10095 & & 3063 & 41. Enerya Karaman doğal gaz & 0.099 & 0.581 & 0.170 & Irs & 5910 & & \\
\hline 10. Aksa Çanakkale doğal gaz & 0.996 & 1.000 & 0.996 & Irs & 42097 & & & 42. Enerya Konya doüal gaz & 0.105 & 0.590 & 0.178 & Irs & & & \\
\hline 11. Aksa Düzce Ereğli doğal & 0.099 & 0.620 & 0.160 & Irs & & & & 43. Esgaz Eskişehir Şehiriçi & 1.000 & 1.000 & 1.000 & - & & & \\
\hline 12. Aksa Elazı̆̆ doğal gaz & 0.106 & 0.681 & 0.155 & Irs & & & & 44. Gazdaş $G c$ & 0.924 & 0.927 & 0.996 & Irs & 36983 & & 24297 \\
\hline 13. Aksa gaz dağıtım & 0.099 & 0.550 & 0.179 & Irs & & & & 45. İgdaş İstanbul gaz & 0.090 & 0.435 & 0.208 & Irs & & & \\
\hline 14. Aksa Gemlik doğal gaz & 1.000 & 1.000 & 1.000 & - & & & & 46. İnegöl gaz & 0.111 & 0.652 & 0.170 & Irs & & & \\
\hline 15.Aksa Gümüşhane Bayburt & 0.954 & 0.984 & 0.969 & Irs & & & 5676 & 47. İzgaz İzmit gaz & 0.104 & 0.540 & 0.193 & Irs & & & \\
\hline 16. Aksa Karadeniz doğal gaz & 0.995 & 1.000 & 0.995 & Irs & 72772 & & & 48. İzmirgaz Şehiriçi doğal gaz & 0.106 & 0.582 & 0.182 & Irs & & & \\
\hline 17. Aksa Malatya doğal gaz & 0.954 & 0.996 & 0.957 & Irs & & & 9044 & 49. Kargaz doğal gaz & 0.103 & 0.621 & 0.165 & Irs & & & \\
\hline 18. Aksa Manisa doğal gaz & 0.102 & 0.634 & 0.161 & Irs & & & & 50. Kargaz Kars Ardahan doğal & 0.933 & 0.941 & 0.992 & Irs & & & 4993 \\
\hline 19.Aksa M.kemalpaşa Susur. & 0.101 & 0.670 & 0.151 & Irs & & & & 51. Kayserigaz Kayseri doğal & 0.106 & 0.572 & 0.185 & Irs & & & \\
\hline 20. Aksa Ordu Giresun d.g. & 0.483 & 0.982 & 0.492 & Irs & & & & 52. Kırgaz Kırlkkale Kırşsehir & 0.100 & 0.605 & 0.165 & Irs & & & \\
\hline 21. Aksa Sivas doğal gaz & 0.105 & 0.646 & 0.162 & Irs & & & & 53. Kizllcahamam doğal gaz & 0.685 & 1.000 & 0.685 & Irs & & & \\
\hline
\end{tabular}


Hünerli, Ö., C., Aydın, Ü. / Journal of Yasar University, 2019, 14 (Special Issue), 133-146

\begin{tabular}{|l|l|l|l|l|l|l|l|l|l|l|l|l|l|l|l|}
\hline 22. Aksa Şanluurfa doğal gaz & 0.964 & 1.000 & 0.964 & Irs & 92084 & & & 54. Palen Enerji doğal gaz & 1.000 & 1.000 & 1.000 & - & & & \\
\hline 23. Aksa Tokat Amasya doğ. & 0.104 & 0.625 & 0.166 & Irs & & & & 55. Palgaz doğal gaz & 0.096 & 0.888 & 0.108 & Irs & & 148249 & \\
\hline 24. Aksa Van doğal gaz & 0.099 & 0.706 & 0.141 & Irs & & & & 56. Polgaz Polatll doğal gaz & 0.102 & 0.678 & 0.150 & Irs & & & \\
\hline 25. Armadaş Arsan Maraş & 0.100 & 0.630 & 0.159 & Irs & & & & 57 . Samgaz doğal gaz & 0.107 & 0.599 & 0.179 & Irs & & & \\
\hline 26. Armagaz Arsan Marmara & 0.102 & 0.645 & 0.158 & Irs & & & & 58. Selçuk doğal gaz & 0.885 & 0.930 & 0.952 & Irs & & & \\
\hline 27. Bahçeşehir gaz & 1.000 & 1.000 & 1.000 & - & & & & 59. Siirt Batman doğal gaz & 0.100 & 0.562 & 0.177 & Irs & 15902 & & \\
\hline 28. Başkent doğal gaz & 0.112 & 0.485 & 0.230 & Irs & & & & 60. Sürmeli doğal gaz & 0.102 & 0.661 & 0.155 & Irs & & & \\
\hline 29. Bursa Şehiriçi doğal gaz & 0.476 & 0.809 & 0.589 & Irs & & & & 61. Torosgaz Isparta Burdur & 0.101 & 0.624 & 0.161 & Irs & & & \\
\hline 30. Çinigaz doğal gaz & 0.506 & 0.906 & 0.559 & Irs & & & & 62. Trakya Bölgesi doğal gaz & 0.966 & 0.969 & 0.997 & Irs & 74868 & & 9617 \\
\hline 31. Çordaş Çorlu doğal gaz & 0.105 & 0.642 & 0.164 & Irs & & & & 63. Udaş Uşak doğalgaz & 0.103 & 0.669 & 0.154 & Irs & & & \\
\hline 32. Çorum doğal gaz & 0.107 & 0.653 & 0.164 & Irs & & & & Ortalama & 0.394 & 0.754 & 0.443 & Irs & 8318 & 2353 & 38397 \\
\hline
\end{tabular}

İlk olarak Dea multi-stage yönteminin ölçeğe göre sabit getirili model (CCR/CRS) olarak hesapladığımız etkinlik skorlarına bakacak olursak; Aksa Gemlik doğal gaz, Bahçeşehir gaz, Enerya Ereğli doğal gaz, Esgaz Eskişehir doğal gaz ve Palen Enerji doğal gaz firmaları tam etkin olduğunu etkinlik skorlarının 1 olmasından çıkarabiliriz. 63 Karar birimi arasından en düşük etkinliğe sahip olan Akmercan Batıkar’ınn ise etkinliği sadece \%0.7 dir. Yani bu karar biriminin \%99.3 (1-0.007) etkinsiz çalıştığını söyleyebiliriz. Yine Diyarbakır doğal gaz ve Enerya Aksaray firmalarının da etkinsizliklerinin \%98'den yüksek olduğu görülmektedir.

Genel olarak sektörün etkinliğini anlayacağımız ortalama değerine baktığımızda sektörünün etkinlik değerinin \% 40 bile olmadığı görülmektedir. Bu oran politika önerimiz ve güncel durum hakkında oldukça dikkat edilmesi gereken bir orandır. Sonuç olarak etkinsizliğin sektörel olarak fazla, tam etkin çalışan firma sayısı da oldukça azdır. Yani doğal gaz dağıtım sektörünün ülke genelinde hala gelişmekte olduğu da bir başka çıkarım olarak dikkat çekmektedir.

Dea multi-stage yönteminin ölçeğe göre değişken getirili (BCC/VRS) olarak hesapladığımız etkinlik skorlarına bakacak olursak; 10, 14, 16, 22, 27, 38, 43, 53 ve 54 numaralı firmaların tam etkin oldukları görülmektedir. Dikkat edecek olursak ölçeğe göre sabit getirili olarak hesapladığımız etkinlik skorlarında etkin çıkan 14, 27, 38 ve 54 numaralı firmaların ölçeğe göre değişken getirili yöntemde de tam etkin çıktığı görülmektedir. Bunun nedeni ölçeğe göre sabit getiri yönteminin aynı zamanda ölçek etkinliğini de kapsarken ölçeğe göre değişken getirili yöntemin böyle bir gerekliliği kapsamayışındandır. Zaten cebirsel olarak ölçeğe göre sabit getiriyi bulurken ölçeğe göre değişken getiri ve ölçek etkinliğinin çarpılmasıyla elde edildiğinden bu durumun matematiksel olarak da ispatlandığı ortadadır. Örneğin Aksa Gümüşhane Bayburt doğal gaz firmasının CRS etkinlik skoru 0.954 iken BCC etkinlik skoru 0.984 olduğundan ölçek etkinlik etkinlik skoru 0.954/0.984=0.969 olarak bulunabilecektir.

Ayrıca ölçeğe göre değişken getiriye göre yaptığımız hesaplamada etkinlik skorlarının yükselmesi de yukarıda saydığımız sebepten ileri gelmektedir. Tablodan da görüldüğü üzere ölçeğe göre sabit getirili yöntemle yapılan hesaplamada \%39,4 olan endüstri etkinliği ölçeğe göre değişken getirili yöntemde \%75.4'e kadar çıkmıştır. Yani ölçek olarak firmaları etkin saymazsak örneklemdeki firmaların daha etkin çalıştıklarını söyleyebiliriz. Ancak burada etkinliğin önemli faktörlerinden biri olan ölçek etkinliğini yok saymamız şartı bulunmaktadır.

CRS modellerinde karar birimleri teknik etkinlik skorlarını benzer ölçekte olmayan diğer karar birimleri ile kıyaslama yaptığı için düşük çıkabilmektedir. Ancak VRS modellerinde benzer ölçekteki karar birimleri kıyaslandığından ölçeğe göre sabit getirili yönteme göre daha yüksek skorlar çıkabilmektedir.

Ölçek etkinliğine bakacak olursak; 14, 27, 38, 43 ve 54 numaralı firmaların ölçek etkinliğinde çalışmakta olduğu görülmektedir. Daha önce de söylediğimiz gibi ölçeğe göre değişken getiri yöntemi, ölçek etkinliğini de kapsadığı için bir karar biriminin ölçeğe göre sabit getiri de etkinlik skorunun 1 çıkması için ölçek etkinliğinin de 1 çıkmasını gerektirecektir. Nitekim elde ettiğimiz bulgular da bu savı desteklemektedir. Ölçek etkinliğinden en uzakta çalışan firmalar olan 2, 33 ve 34 numaralı karar birimleri sırasıyla \%90, \%82 ve \%85 oranında kendi ölçeklerinden daha uzakta çalışmaktadır.

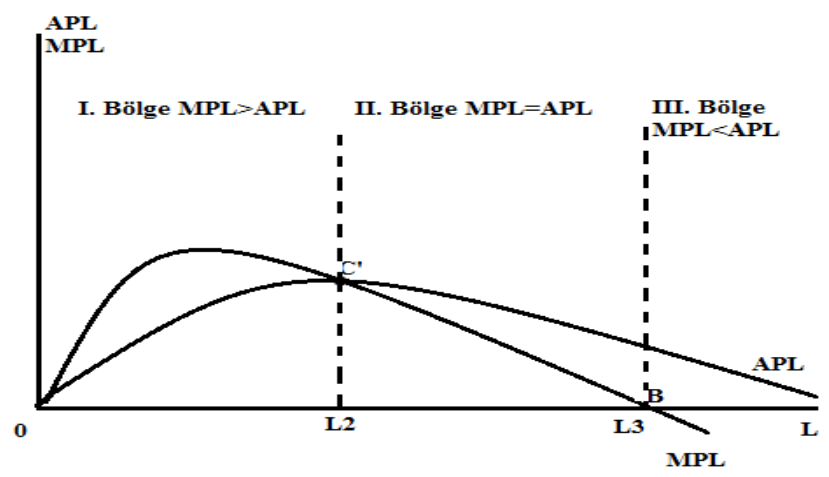

Şekil 4. Üretimin Bölgeleri

Kaynak: Özdemir 2013, 139 
Son olarak dikkat edecek olursak tam etkin olan firmalar dışındaki tüm firmalar ölçeğe göre artan getiride çalışmaktadır. Bunu tablodaki son sütunda yazan irs ibaresinden anlayabiliriz. Bunun anlamı verimlilik analizinde firmanın birinci bölgesine tekabül eden artan verimler bölgesinde dengede olduğudur. Bu bölgede firmanın marjinal verimliliği ortalama verimliliğinden yüksek olduğundan firma üretimini artırmalıdır. Bu bahsedilen bölge ise üretimin birinci bölgesidir. Bu bölgede yer alan firmalar daha çok kapasite artırarak çalışmakta nihayetinde eskisine oranla daha çok girdi kullanarak daha çok çıktı üretebilmektedir (Özdemir vd. 2013, 132-139). Yani bu 63 karar biriminden tam etkin olmayan karar birimleri henüz olgunluğa erişememiş hala pozitif ölçek ekonomilerine sahiptirler. Ancak üretimi artırdıklarına bu atıl kalan kapasiteden kurtulabilecektir. İlk bölümde açıkladığımız uzun dönem ortalama maliyet ya da zarf eğrisi dediğimiz eğrinin negatif eğimli olduğu kısımda örneklemdeki etkin olmayan tüm firmalar bulunmaktadır ve bu bölge ölçek olarak optimum nokta kabul edilmediğinden artan verimler bölgesi içerisinde üretim devam etmelidir. Yani etkin olmayan doğal gaz dağıtım firmalarının yeterli miktarda dağıtımlarını gerçekleştiremediğini söyleyebiliriz. Etkinlik skorları sonuçlarından anlaşıldığı üzere dikkat çeken bir diğer nokta da ölçeğe göre sabit ve değişken getirili modeller arasında yüksek farklılığın çıkmasıdır. Bu fark ülkemizdeki doğalgaz endüstrisinin henüz ölçek olarak etkin olmayan bir durumda olduğuna işaret etmektedir. Nitekim etkin olmayan tüm karar birimlerinin ölçeğe göre artan getiride çalışmasından da bu sonucu çıkarabilmekteyiz.

Ölçeğe göre değişken getirili yönteme göre Çelik boru hattı uzunluğu girdisi yönünden aylaklığa yani atıl kalan girdiye sahip olan karar birimleri 8, 9, 10, 16, 22, 37, 41, 44, 59 ve 62 numaralı firmalardır. Polietilen boru hattı uzunluğu girdisi yönünden aylak girdisi olan tek karar birimi 55 numaralı firmadır. Kadrolu Personel Sayısı girdisi yönünden aylak girdiye sahip olan karar birimleri ise; 3, 9, 15, 17, 35, 44, 50 ve 62 numaralı firmalardır. Bu firmalar istihdam etmeleri gereken optimal personel sayısından fazlasını istihdam etmektedirler. Yani bu firmalar için emek faktörünün optimum miktarının aşıldığını söyleyebiliriz.

\subsection{Referans Kabul Edilen Firmalar, Referans Kabul Edilme Yoğunlukları ve Referans Olma Frekansları}

Tablo 5. Referans Alınan Karar Birimleri ve Ağırlıkları

\begin{tabular}{|c|c|c|c|c|c|c|c|c|c|c|c|c|c|c|c|c|c|c|c|}
\hline \multirow[b]{2}{*}{ Firmalar } & \multicolumn{4}{|c|}{$\begin{array}{l}\text { Referans } \\
\text { Alınan } \\
\text { Karar } \\
\text { Birimleri } \\
(\text { BCC }) \\
\end{array}$} & \multicolumn{4}{|c|}{\begin{tabular}{|} 
Referans Olarak \\
Gösterilen Firmaların \\
A ğırlıkları (BCC)
\end{tabular}} & \multirow[t]{2}{*}{\begin{tabular}{|c|} 
Toplamda \\
Referans \\
Alınma \\
Saylst \\
$(B C C)$ \\
\end{tabular}} & \multirow[b]{2}{*}{ Firmalar } & \multicolumn{4}{|c|}{$\begin{array}{c}\text { Referans } \\
\text { Alınan Karar } \\
\text { Birimleri } \\
\text { (BCC) }\end{array}$} & \multicolumn{4}{|c|}{$\begin{array}{c}\text { Referans Olarak } \\
\text { Gösterilen Firmaların } \\
\text { Ağırlıkları (BCC) }\end{array}$} & \multirow[t]{2}{*}{\begin{tabular}{|c|} 
Toplamda \\
Referans \\
Alınma \\
Saylst \\
$(B C C)$ \\
\end{tabular}} \\
\hline & 1. & 2. & 3. 4 & 4. & 1. & 2. & 3. & 4. & & & 1. & 2. & 3. & 4. & 1. & 2. & 3. & 4. & \\
\hline 1. Agdaş Adapazarl gaz & 38 & 165 & 545 & & $0.023 \mid 0$ & 0.293 & 0.367 & 0.317 & & 33. Diyarbakır doğal gaz & 53 & 54 & 16 & & 0.4210 & 0.2120 & 0.367 & & \\
\hline $\begin{array}{l}\text { 2. Akmercan Batıkar doğal } \\
\text { gaz }\end{array}$ & 53 & 54 & 16 & & 0.3330 & 0.304 & 0.362 & & & $\begin{array}{l}\text { 34. Enerya Aksaray doğal } \\
\text { gaz. }\end{array}$ & 53 & 16 & 54 & & $0.336 \mid 0$ & $0.294 \mid 0$ & 0.370 & & \\
\hline 3. Akmercan Delta doğal gaz & 38 & 53 & 16 & & 0.9160 & 0.039 & 0.045 & & & 35. Enerya Antalya doğal gaz & 38 & 16 & 53 & & 0.8360 & 0.1190 & 0.045 & & \\
\hline 4. Akmercan Gepa doğal gaz & 38 & 54 & $53 \mid 1$ & & 0.8320 & 0.025 & 0.062 & 0.080 & & 36. Enerya Aydın doğal gaz & 38 & 54 & 53 & 160 & 0.7980 & 0.0420 & 0.015 & 0.145 & \\
\hline 5. Akmercangaz doğal gaz & 38 & 545 & 531 & & 0.0120 & 0.321 & 0.364 & 0.302 & & 37. Enerya Denizli doğal gaz & 10 & 27 & 38 & 160 & 0.8750 & 0.0070 & 0.000 & 0.118 & \\
\hline 6. Aksa Afyon doğal gaz & 38 & 54 & 531 & & 0.0120 & 0.312 & 0.359 & 0.317 & & 38. Enerya Ereğli doğal gaz & 38 & & & & 1.000 & & & & 42 \\
\hline 8. Aksa Bandırma doğal gaz & 16 & & & & 0.469 & 0.531 & & & & 40. Enerya Kapadokya doğ.g. & 38 & 54 & 53 & 160 & 0.0190 & $0.295 \mid 0$ & 0.368 & 0.318 & \\
\hline $\begin{array}{l}\text { 9. Aksa Bilecik Bolu doğal } \\
\text { gaz }\end{array}$ & 22 & & & & 0.049 & 0.951 & & & & 41. Enerya Karaman doğal g. & 16 & 22 & & & $0.462 \mid 0$ & 0.538 & & & \\
\hline 10. Aksa Çanakkale doğal gaz & 10 & & & & 1.000 & & & & 4 & 42. Enerya Konya doüal gaz & 38 & 54 & 53 & 160 & 0.0320 & 0.2870 & 0.358 & 0.323 & \\
\hline 11. Aksa Düzce Ereğli doğal & 38 & 16 & 545 & & 0.020 & 0.312 & 0.318 & 0.350 & & 43. Esgaz Eskişehir Şehiriçi & 43 & & & & 1.000 & & & & 1 \\
\hline 12. Aksa Elazlğ doğal gaz & 38 & 16 & 545 & & 0.0180 & 0.301 & 0.357 & 0.325 & & $\begin{array}{l}\text { 44. Gazdaş Gaziantep doğal } \\
\text { g }\end{array}$ & 10 & 27 & 38 & & $0.996 \mid 0$ & 0.0040 & 0.001 & & \\
\hline 13. Aksa gaz dağıtım & 38 & 54 & 531 & & 0.0230 & 0.232 & 0.368 & 0.377 & & 45. İgdaş Ístanbul gaz & 38 & 16 & 53 & 540 & 0.0390 & 0.4050 & 0.464 & 0.092 & \\
\hline 14. Aksa Gemlik doğal gaz & 14 & & & & 1.000 & & & & 1 & 46. İnegöl gaz & 38 & 54 & 53 & 160 & 0.0210 & $0.244 \mid 0$ & 0.430 & 0.305 & \\
\hline 15.Aksa Gümüşhane Bayburt & 38 & 165 & 53 & & 0.9120 & 0.052 & 0.036 & & & 47. İzaz İzmit gaz & 38 & 54 & 53 & 160 & 0.0380 & 0.2070 & 0.401 & 0.355 & \\
\hline 16. Aksa Karadeniz doğal gaz & 16 & & & & 1.000 & & & & 49 & 48. İzmirgaz Şehiriçi doğal g. & 38 & 16 & 54 & 530 & 0.0360 & 0.3150 & 0.295 & 0.353 & \\
\hline 18. Aksa Manisa doğal gaz & 38 & 54 & 531 & & 0.018 & 0.295 & 0.359 & 0.327 & & 50. Kargaz Kars Ardahan d.g & 38 & 53 & 16 & & 0.9330 & 0.0100 & 0.057 & & \\
\hline 19.Aksa M.kemalpaşa Susur. & 38 & 54 & 531 & & 0.006 & 0.354 & 0.291 & 0.349 & & 51. Kayserigaz Kayseri doğal & 38 & 16 & 54 & 530 & 0.0350 & 0.3380 & 0.248 & 0.379 & \\
\hline 20. Aksa Ordu Giresun d. lg. & 53 & $16=$ & 54 & & 0.0430 & 0.050 & 0.907 & & & 52. Kırgaz Kırıkkale Kırşehir & 38 & 54 & 53 & 160 & 0.0230 & 0.2820 & 0.375 & 0.319 & \\
\hline 21. Aksa Sivas doğal gaz & 38 & 54 & 531 & 160 & 0.0230 & 0.310 & 0.364 & 0.303 & & 53. Klzılcahamam doğal gaz & 54 & & & & 1.000 & & & & 45 \\
\hline 22. Aksa Şanlıurfa doğal gaz & 22 & & & & 1.000 & & & & 5 & 54. Palen Enerji doğal gaz & 54 & & & & 1.000 & & & & 40 \\
\hline
\end{tabular}


Hünerli, Ö., C., Aydın, Ü. / Journal of Yasar University, 2019, 14 (Special Issue), 133-146

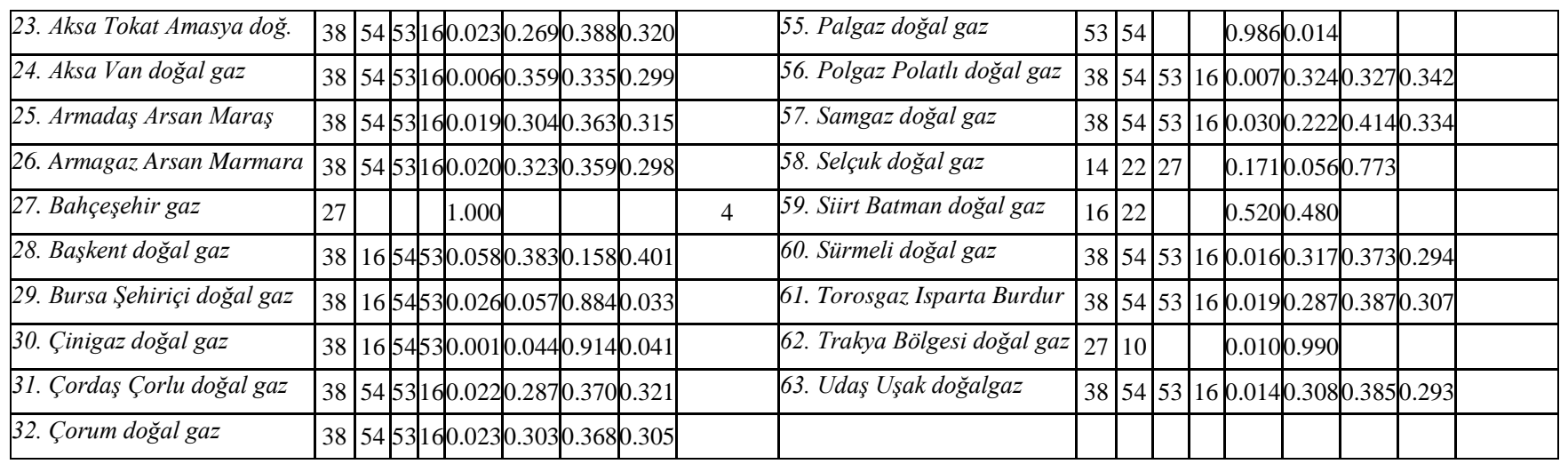

Bu tablo firmaların model alması gereken etkin firmaları göstermektedir. Çünkü etkin olmayan bir firma etkin olan başka bir firmayı rol model alarak etkinliğe ulaşabilecektir. Bu tabloda da etkin olmayan karar verici birimlere örnek alması gereken bazı karar verici birimler önerilecektir.

Ölçeğe göre değişken getirili yöntemde Akmercan Batıkar doğal gaz dağıtım firmasına sırasıyla 53 (Kızılcahamam doğal gaz), 54 (Palen Enerji doğal gaz) ve 16 (Aksa Karadeniz doğal gaz) numaralı firmaları model alması önerilmektedir. Dikkat edecek olursak önerilen bu 53, 54 ve 16 numaralı firmalar ölçeğe göre değişken getiri altında tam olarak etkindir. Etkin olmayan firmalar diğer firmalara hiçbir şekilde referans olarak gösterilememektedir. Zaten etkinsiz bir firmanın örnek alınması nihayetinde girdi kullanımında hiçbir firmayı etkin hale getiremeyecektir.

Tablo 5'de, bir karar verici birime rol olarak önerilen karar verici birime ağırlık olarak ne kadar benzemesi gerektiği de gösterilmektedir. Yani bu tablo bir firmanın örnek aldığı firmayı ne kadar fazla referans alması gerektiğini söylemektedir. Yine çalışmamızdaki en etkinsiz karar verici birim olan 2 numaralı firma olan Akmercan Batıkara bakacak olursak;

Bu karar verici birim;

Ölçeğe göre değişken getiri (BCC) varsayımı altında;

- \%33,3 oranında 53 (Kızılcahamam doğal gaz dağıtım)

- $\quad \% 30,4$ oranında 54 (Palen Enerji doğal gaz dağıtım)

- $\quad \% 36,2$ oranında 16 numaralı (Aksa Karadeniz doğal gaz dağıtım) firmalarını model olarak almalıdır.

Burada dikkat edilmesi gereken bir diğer konu ise, tam olarak etkin olan firmanın rol model olarak yine kendini alması gerektiğidir. Bu etkinliğin sürdürülebilir olması için yapılan bir saptamadır. Etkin olmayan firmalar ise model alacakları firmalarla birlikte ne kadar oranda o firmaları model almaları gerektiklerini de göz önünde bulundurduklarında etkinliklerini artırabilecek ve etkin olabileceklerdir.

Yine Tablo 5, bir firmanın kaç kez diğer firma(lar)ca referans alındığını göstermektedir. Örneğin Ölçeğe göre değişken getiride 54 numaralı firma Palen enerji doğal gaz dağıtım 40 kez referans olarak alınmaktadır. Yani etkin bir firmanın ölçeğe göre sabit ve değişken getirili modellerde kaç kez diğer firmalarca model alınacağını gösteren bu tablo etkin olan firmalara bir anlamda endüstride şahsi önem de kazandırıyor diyebiliriz. Burada bir firma için tam etkinliğin tek başına en iyi standart ya da referans olarak kabullenilmesine yetmemektedir. O nedenle en etkin firmaların kaç kere referans alındığını bilmek gerekmektedir. Ancak bu şekilde en iyi referans olan firma belirlenmekte ve böylece diğerleri için öncelikli bir standart belirlenebilmektedir.

\subsection{Malmquist Toplam Faktör Verimliliği ve Analiz Sonuçları}

Malmquist yıllar içerisindeki değişimi veren dinamik bir analizdir. Cobb-douglas üretim fonksiyonunda girdilerdeki ortak değişim olan ölçekteki değişimi VZA ile ölçerken fonksiyonun önündeki A (teknoloji) katsayısındaki değişimi ise Malmquist toplam faktör verimliliği ile ölçmekteyiz. Yani uzun dönemli etkinlik ölçütü olan tüm faktörlerdeki beraber değişimi gösteren bu katsayı firma uzun dönem dengesi için yol gösterici bir niteliktedir. Bununla birlikte teknolojik değişmenin değişmesi; ilerlemesi ya da gerilemesi durumlarının altında yatan sebeplerin neler olduğunu göstermektedir. Mikro anlamda yukarıda bahsedildiği şekilde açıklanabilen TFP makro anlamda ise endüstri büyümesindeki değişim hakkında bize uzun dönemli bir analiz sunabilmektedir.

Teknik etkinlik, teknolojik değişim, pür ekonomik etkinlikteki değişim, ölçek etkinliğindeki değişim ve toplam faktör verimliliğindeki değişimleri ölçmektedir. Uzun süreli toplamda teknolojideki olan verimlilikteki değişmeleri farklı farklı alt kollara ayırarak açıklamaya çalışan bu yaklaşım Türk doğal gaz dağıtım endüstrisinde çalışan firmaların uzun dönemde etkinliği yakalayabilmesi için önemli bir stratejik kaynaktır. Bir diğer dikkat etdilmesi gereken durum da 33 numaralı firmadaki olduğu gibi çok yüksek hatta patlayan nitelikli değişim skorlarının gerçekleşmesidir. Böylesine abartılı bir artış ise gerçekten bizzat teknik etkinlikteki firma yönetimi için çığır açıcı nitelikte bir yatırım oluşumundan ya da ölçüm hataları (veri kaybı) durumunun ortaya çıkacak olmasından kaynaklanabilmektedir. O nedenle böyle bir değişim sonucunun bileşimine bakmak için parametrik diğer analizlere bakmak gerekmektedir.

$\Delta$ Teknik etkinlik skoru firmaların teknik etkinliklerindeki bir önceki yıla göre olan değişimini vermektedir. $\Delta$ Teknik etkinlik skorunun ortalama değerine baktığımızda bu ise bize toplam doğalgaz dağıtım endüstrisindeki teknik etkinliğin 
bir önceki yıla göre olan değişimini vermektedir. Bu değere baktığımızda skorun 0.546 olduğunu görmekteyiz. Yani 2013 yılından 2014 yılında geçerken genel doğalgaz dağıtım endüstrisindeki teknik etkinliğin \%45,4 azaldığını görmekteyiz (1-0.546=0.454). Şimdi benzer bir analizi Tablo 6'ya bakarak 2015 yılı için yapmak gerekirse bu y1lda ortalama etkinlikte bir önceki yıla oranla yaklaşık \%69.3'lük bir artış olduğu görülmektedir. Ek tablo 7'den de 2015 yılından 2016 'ya geçerken ise bu artışın çok daha yüksek boyutlara ulaşarak \%100'den de fazla arttığı görülmektedir. Burada unutulmaması gereken bir başka faktör de burada bahsedilen etkinlik değişiminin ölçeğe göre sabit getiri altındaki etkinlik değişiminin olduğudur. Yani bu değişim CCR etkinlik skorlarının değişimine yakınsayan bir değişim parametresidir.

Bir başka skor olan $\Delta$ Teknoloji skoruna baktığımızda bu skor da bize üretim teknolojisindeki değişimin bir önceki yıla göre olan değişimini göstermektedir. Yine bize genel olarak doğalgaz dağıtım endüstrisindeki teknolojik değişimi verecek olan ortalama değerine baktığımızda skorun 1.418 olduğunu görmekteyiz. Yani bu iki karar verici birimin aksine genel endüstride teknoloji \% 41.8 oranında gelişmiştir. Parametrenin adından da anlaşılacağı üzere üretim teknolojisindeki bu artış bize endüstri için kritik bilgiler sunmaktadır. Temel olarak üretim teknolojisindeki değişikliği eş ürün eğrilerindeki faktör bileşimleri eğrisinin yer değiştirmesi olarak tanımlandığını biliyoruz. Burada da kastedilen durumun bunun bir benzeridir. Yani aynı üretim artık hem nicelik hem de nitelik bakımından daha optimal bileşimlerle gerçekleşmektedir. Ancak unutulmaması gereken nokta ise bu parametrenin değişim parametresi olduğudur. Yani optimal denge denirken burada kastedilen t-1 döneme göre $t$ dönemindeki değişmedir. Kısacası göreceli (zamansal) bir değişimdir ve mutlak bir optimalizasyondan bahsedebilmek henüz mümkün değildir.

Üçüncü değişken parametre olan $\Delta$ Pür (Saf) Ekonomik Etkinlik değişkenine baktığımızda bu değer bize karar verici birimlerin Pür ekonomik etkinliklerindeki değişimi vermektedir. Genel olarak endüstrinin pür ekonomik etkinliğindeki değişmeye bakarsak skorun 0.934 olduğunu görebiliriz. Bu demektir ki endüstrinin pür ekonomik etkinliği 2014 yılında bir önceki yıla göre \%6.6 azalmıştır. Kaldı ki zaten $\Delta$ Pür Ekonomik Etkinlik $<\Delta$ Ölçek Etkinlik olması durumunda $\Delta$ Teknik Etkinlik parametresinde hiçbir zaman uzun dönemli bir artış sağlanamayacaktır. Çünkü teknik etkinlik bu iki değişim parametresinin bilmeşiminden meydana gelmektedir.

Dördüncü değişken $\Delta$ Ölçek Etkinlik'de bize firmanın ölçeğindeki etkinliğin önceki yıla göre olan değişimini vermektedir. Genel olarak Doğalgaz dağıtım endüstrisinin ölçek etkinliğindeki değişim ise 0.585'dir. Yani endüstrinin ölçek etkinliği 2014 yılında bir önceki yıla göre \%41.5 (1-0.585) azalmıştır.

Son değişkenimiz olan $\triangle \mathrm{TFV}$ ise bize karar verici birimlerin bir önceki yıla göre toplam faktör verimliliklerinin değişimini vermektedir. Bu değer de teknik etkinlikteki değişim $\Delta$ Teknik Etkinlik ile teknolojideki değişimin $\Delta$ Teknoloji ile çarpılması suretiyle bulunmaktadır. Genel olarak endüstrinin skoruna baktığımızda ise toplam faktör verimliliğinin önceki yıla göre \%22.6 azaldığını göstermektedir. Hem üretim teknolojisindeki değişimi hem de girdi (çıtı) kullanımı ve üretimindeki optimalizasyonu kapsadığından diğer tüm değişim parametrelerinden çok daha geniş kapsamlı bir değişim parametresidir. Bu parametrenin yüksek olduğu firmalar sadece teknik, ölçek, pür ekonomik etkinlikte ve teknolojisinde değil tüm bu değişim parametrelerindeki hepsindeki iyileşmeyi kapsadığından en çok dikkat çeken geniş kapsamlı bir parametredir.

Tablo 6. Yıllar Bazında Değişim Parametrelerinin Değişimi

\begin{tabular}{|c|c|c|c|c|c|}
\hline$Y_{l} l$ & $\Delta T . E$. & $\Delta T$ & $\Delta P . E . E$. & $\Delta \ddot{O} . E$. & $\Delta T F V$ \\
\hline 2014 & 0.546 & 1.418 & 0.934 & 0.585 & 0.774 \\
\hline 2015 & 0.708 & 1.693 & 0.875 & 0.809 & 1.198 \\
\hline 2016 & 2.271 & 0.378 & 1.050 & 2.163 & 0.858 \\
\hline Ortalama & 0.958 & 0.968 & 0.950 & 1.008 & 0.927 \\
\hline
\end{tabular}

Açıklama: $\Delta$ T.E.:Teknik Etkinlikteki Değişme, $\Delta$ T:Teknolojideki Değişme, $\Delta$ P.E.E:Pür Ekonomik Etkinlikteki Değişme, $\Delta$ Ö.E.:Ölçek Etkinliğindeki Değişme, $\Delta$ T.F.V.: Toplam Faktör Verimliliğindeki Değişme,

Tablo 6'dan hareketle dikkat etmemiz gereken bir başka nokta da toplam faktör verimliliğinin değişiminin dengesiz bir seyir izlediğidir. Çünkü 2013 yılından 2014 yılına geçerken bir miktar düşen oran, 2014'den 2015 y1lında geçerken artmıştır. Ve bu oran da tablodan görüleceği üzere \%19.8'dir. Daha sonra 2016 yılına geçerken bu oran $\% 0.73$ kadar tekrar azalmıştır. Bu sonuçlardan hareketle sektörün henüz olgun bir seviyeye gelmediği sonucunu çıkarmak zor değildir. Nasıl ki ülkelerin büyüme oranında dalgalanma olduğunda üretimdeki istikrarsızlıktan bahsediyorsak daha mikro kapsamlı bu sektör içinde aynı iddiayı öne sürebiliriz. Zaten tam etkin firmalar dışındaki tüm firmaların ölçeğe göre artan getiride çalışıyor olması uzun dönemdeki üretim dengesinde optimal dengeye ulaşılamadığını çalışmada daha önce de dile getirmiştik. Optimal dengeye ulaşana kadar olgunlaşmaya başlayan bu piyasa gerekli birtakım regülasyonların da desteği ile optimum dengesini yakalayabilecek ve ülke ekonomisi üzerinde daha katma değer yaratan bir sektör olabilecektir. Fakat doğal gaz piyasası genelinde ülkemizin dışa olan bağımlılığının devam etmesinden ötürü küresel, coğrafik ve politik anlamda bir çok olumsuz faktöre karşı kırılgan bir durumda oluşu da sektörde yaratılmaya çalışan optimal dengeyi kolayca sağlayamayabilecektir. Yani ülkemiz bazında doğal kaynak olarak son derece kıt olan bu enerjinin dağıtım ve kullanımının en verimli hali şu an ne yazık ki sadece kendi ülkemiz dinamiklerine bağlı değildir. Bu nedenle sadece teknik anlamda değil etkin hale gelebilmek için birçok konuda hassas olunması gerektiği açık olan bir gerçekliktir. Ayrıca ara mal niteliği olan sektörleden biri olan doğal gaz sektörü Türkiye Ekonomisini uzunca bi süre döviz darboğazı yaşatmıştır. İşte tam olarak da bu gibi nedenlerden ötürü bu sektörün önemi son derece önemlidir. 
Hünerli, Ö., C., Aydın, Ü. / Journal of Yasar University, 2019, 14 (Special Issue), 133-146

Tablo 7. Firma Bazında Faktör Verimliliği Değişimleri (2013-2016)

\begin{tabular}{|c|c|c|c|c|c|c|c|c|c|c|c|}
\hline Firmalar & $\triangle T . E$. & $\Delta T$ & UP.E.E. & $\Delta \ddot{O} . E$. & $\triangle T F V$ & Firmalar & $\Delta T . E$. & $\Delta T$ & UP.E.E. & $\Delta \ddot{O} . E$. & $\triangle T F V$ \\
\hline 1. Agdaş Adapazarl gaz & 023 & 0.824 & 0.922 & 1.109 & 0.842 & 33. Diyarbakır doğal gaz & 2.185 & 1.307 & 0.957 & .284 & 2.856 \\
\hline 2. Akmercan Batıkar doğal gaz & 2.502 & 0.986 & 0.905 & 2.765 & 2.466 & 34. Enerya Aksaray doğal gaz & 3.896 & 0.633 & 1.086 & 3.589 & 2.465 \\
\hline $3 . A k 7$ & 0.477 & 1.163 & 0.819 & 0.583 & 0.555 & 35. Er & 0.498 & 0.757 & 0.841 & 0.592 & 0.377 \\
\hline 4. Akmercan Gepa doğal gaz & 1.049 & 0.757 & 1.020 & 1.029 & 0.795 & 36. Enerya Aydın doğal gaz & 0.491 & 0.983 & 0.832 & 0.590 & 0.483 \\
\hline$\overline{5 . A R}$ & 2.178 & 1.457 & 1.154 & 1.888 & 3.174 & 37. & 0.841 & 0.985 & 0.944 & 0.891 & 0.828 \\
\hline 6. Aksa Afyon doğal gaz & 1.020 & 0.894 & 0.927 & 1.100 & 0.911 & 38. E & 0.474 & 0.972 & 0.825 & 0.575 & 0.461 \\
\hline 7. Aksa Ballkesi & 2.121 & 0.483 & 1.144 & 1.854 & 1.025 & 39. Enerya Erzincan doğal gaz & 1.026 & 0.965 & 0.978 & 1.049 & 0.990 \\
\hline $8 . A$ & 1.022 & 0.968 & 0.981 & 1.042 & 0.990 & 40. & 1.015 & 0.989 & 0.933 & 1.088 & 1.004 \\
\hline 9. Aksa B & 0.995 & 0.769 & 1.006 & 0.989 & 0.765 & $41 . E$ & 0.485 & 0.979 & 0.977 & 0.496 & 0.475 \\
\hline 10. Aksa Çanak & 0.481 & 0.996 & 0.807 & 0.595 & 0.479 & 42. En & 1.013 & 0.697 & 0.933 & 1.086 & 0.707 \\
\hline$\overline{11 . A k}$ & 1.012 & 1.163 & 0.926 & 1.094 & 1.177 & 43. & 0.481 & 1.813 & 0.789 & 0.610 & 0.873 \\
\hline 12. A & 1.013 & 1.169 & 0.918 & 1.104 & 1.184 & 44. $G$ & 0.484 & 0.999 & 0.802 & 0.603 & 0.483 \\
\hline 13. Aksa gaz dă̆ıtım & 2.130 & 0.757 & 1.203 & 1.770 & 1.612 & 45. İgdaş Ist & 1.907 & 0.633 & 1.198 & 1.592 & 1.206 \\
\hline 14. Al & 0.476 & 0.970 & 0.833 & 0.571 & 0.461 & 46. & 1.000 & 0.896 & 0.935 & 1.070 & 0.896 \\
\hline$\overline{15 . A}$ & 1.016 & 0.986 & 1.005 & 1.010 & 1.002 & 47.1 & 1.015 & 0.988 & 0.956 & 1.062 & 1.004 \\
\hline 16. Aksa Karadeniz doğal gaz & 0.481 & 1.000 & 0.810 & 0.594 & 0.481 & 48. $\dot{I} z$ & 1.017 & 1.149 & 0.926 & 1.099 & 1.169 \\
\hline 17. $A k$ & 1.014 & 1.403 & 1.001 & 1.013 & 1.423 & 49. & 0.470 & 0.987 & 0.928 & 0.507 & 0.464 \\
\hline 18. Aksa Ma & 1.023 & 0.982 & 0.935 & 1.094 & 1.005 & 50.1 & 0.945 & 0.776 & 0.998 & 0.947 & 0.733 \\
\hline 19.Aksa M.kemc & 1.016 & 0.681 & 0.923 & 1.100 & 0.691 & $51 . K$ & 104 & 0.995 & 205 & 1.746 & 2.094 \\
\hline 20. AksaO & 0.607 & 1.277 & 0.812 & 0.748 & 0.776 & $52 . K$ & 1.018 & 0.892 & 0.939 & 1.085 & 0.909 \\
\hline 21. $A k$ & 0.472 & 0.986 & 0.927 & 0.509 & 0.465 & 53. & 0.949 & 1.381 & 1.000 & 0.949 & 1.310 \\
\hline 22. Aksa Şanlıurfa doğal gaz & 1.006 & 0.987 & 1.000 & 1.006 & 0.993 & 54. Palen En & 0.483 & 1.157 & 0.813 & 0.594 & 0.559 \\
\hline 23. Aksa Tokat Am & 0.472 & 0.993 & 0.926 & 0.510 & 0.469 & 55.1 & 1.066 & 1.264 & 0.829 & 1.287 & 1.348 \\
\hline $24 . A k$ & 2.114 & 0.752 & 1.123 & 1.882 & 1.590 & $56 . P$ & 1.017 & 1.154 & 0.931 & 1.093 & 1.173 \\
\hline 25. Armadaş Arsan Maraş & 2.072 & 0.767 & 1.140 & 1.818 & 1.589 & 57. Samgaz doğal gaz & 1.017 & 1.152 & 0.948 & 1.074 & 1.172 \\
\hline 2 26. $A r n$ & 1.016 & 0.988 & 0.921 & 1.103 & 1.004 & 58 & 1.024 & 0.985 & 1.007 & 1.017 & 1.008 \\
\hline 27. Bahçeşehir gaz & 1.000 & 1.007 & 1.000 & 1.000 & 1.007 & 59. S & 1.037 & 0.977 & 0.992 & 1.046 & 1.013 \\
\hline 28. Başkent doğal gaz & 1.014 & 0.988 & 0.965 & 1.051 & 1.002 & 60. Sürmeli doğal gaz & 1.005 & 1.195 & 0.927 & 1.085 & 1.201 \\
\hline 29. Bursa Şehiriçi doğal gaz & 0.617 & 1.262 & 0.829 & 0.743 & 0.778 & 61.7 & 0.475 & 1.162 & 0.932 & 0.510 & 0.552 \\
\hline $30 . C$ & 0.640 & 1.201 & 0.832 & 0.769 & 0.769 & 62.7 & 0.938 & 0.752 & 0.953 & 0.985 & 0.706 \\
\hline 31. Çordaş Çorlu doğal gaz & 1.782 & 0.825 & 1.109 & 1.607 & 1.470 & 63. Udaş Uşak doğalgaz & 1.024 & 0.985 & 0.932 & 1.099 & 1.009 \\
\hline 32. Çorum doğal gaz & 2.082 & 0.584 & 1.153 & 1.806 & 1.216 & & 0.958 & 0.968 & 0.950 & 1.008 & 0.927 \\
\hline
\end{tabular}

Tablo 7'de tek tek firma bazında bu dört yıllık dönemde ortalamada skorlarının nasıl değiştiği görülmektedir. Örneğin 1. firmanın teknik etkinlikteki değişme değerinin ortalaması 1.023 çıkmıştır. Yani bu firmanın dört yılda ortalamada \%2.3'lük bir teknik etkinlik artışı gösterdiğini gözler önüne sermektedir. Yani teknik olarak firmanın teknik ve yönetsel anlamda bir atış olduğu aşikârdır. Aynı firmanın dört yıldaki ortalama teknolojik değişimi ise 0.824 olması da teknolojisinde \%17.6'lık bir gerileme olduğuna, pür ekonomik etkinlikte de \%7.8'lik bir azalışa işaret etmektedir. Ancak bu firmanın ölçek etkinliğinde \%10.9'luk bir artış gözlemlenirken toplam faktör verimliliğinde de \%15.8'lik bir azalış dikkati çekmektedir. Bu şekilde bakıldığında çokta bir anlam ifade etmeyen bu sayılar ancak ve ancak göreceli olarak değerlendirildiğinde anlam kazanacaktır. Agdaş Adapazarı doğal gaz dağıtım A.Ş.'nin bu dört yıllık süreçte teknik etkinliğindeki artış küçük bir yüzdeye karşılık gelmesine rağmen ortalamadan daha çok teknik etkinlik artışı olduğu açıktır. Teknik etkinlikteki bu artışın ise altında yatan sebep olarak bu parametreyi etkileyen başka bir parametre olan ölçek etkinliğine de bakmamız gerekir. Firmanın ölçek etkinliğinde yakaladığı artış ise \%10.9 gibi ciddi bir büyüme oranıdır. Burada sorulması gereken öncelikli soru neden doğru orantılı olmasına rağmen firmanın hem teknik etkinlik hem de ölçek etkinliği değerlerinde aynı oranda büyüyemediğidir. Bunun cevabı ise pür (saf) ekonomik etkinlikte yaşanan düşüştür. Dikkat edilecek olursa firmanın pür ekonomik etkinliğinin dört yllsonunda \%7.8 gibi küçümsenmeyecek bir oranda azaldığıdır. Yani firma ölçek etkinliğindeki büyümesini yüksek miktarda tutabilmesine rağmen pür ekonomik dinamiklerinin (ölçek dışı iyileşmeler; pazarlama stratejileri gibi) iyi işleyememesi nedeniyle genel anlamda teknik etkinliğindeki artış sınırlı kalmıştır. Firmanın toplam faktör verimliliğindeki değişmelere baktığımızda teknik etkinlik ve teknolojik değişimlerinden oluşan bu değişken için durumun dört sene içinde kötüleştiğidir. 
Teknik etkinliğin yorumlanmasında ana hatlar olan faktör kullanımının yıllar bazında bir miktar iyileşirken genel teknolojik anlamda oldukça gerileyen (\%17.6) firma bu iki değişim parametresinden oluşan toplam faktör verimliliği konusunda \%15.8 gibi bir oranda gerilemiştir. Yani firma teknik dinamikleri dışındaki etmenlerden olan beşeri sermaye, işletme içi yönetişim, insan kaynakları gibi sosyal sermaye konularında firmanın başarılı olamadığına işaret etmektedir.

Mikro anlamdaki yukarıdaki analizimizden hareketle artık endüstri için TFV'nin nasıl değiştiğini yorumlayabiliriz. Doğalgaz endüstrisinin genel olarak analizine bakacak olursak; 2013-2016 yılları aralığında endüstrideki toplam teknik etkinlikteki değişim \% 4.2 'lik bir düşüşe işaret etmekteyken, teknolojideki gerileme $\% 3.2$ ve pür ekonomik etkinlikte ise \%5.2'lik bir küçülme yaşanmaktadır. Ölçek etkinliğindeki \%0.8'lik ufak bir artışa rağmen toplam faktör verimliliğinde \%7.3'lük bir küçülme söz konusudur. Yukarıdaki analizimizi buraya benchmark etmek gerekirse; teknik etkinlikteki \%4.2'lik düşüş ve ölçek etkinliğindeki \%0.8 artış sonucunda pür ekonomik etkinliğin değişimi \% 5 'lik bir düşüş olmuştur. Görüldüğü gibi teknik etkinlikteki düşüş ve ölçek etkiliğindeki artışın bölünmesi ile yaklaşık \%5 değeri elde edilebilmektedir. Yani endüstrideki girdi kullanım miktarı ile yakın ilişkili olan ölçek etkinliğindeki artışa rağmen pür ekonomik etkinlikteki yüksek miktarlı artış sonuç olarak endüstri bazında teknik etkinlikte bir artışa neden olmuştur. Bununla birlikte teknolojik değişimdeki \%3.2'lik gerileme sonucu, teknik etkinlikteki gerilemenin de etkisi ile toplam faktör verimliliği tüm etkinlik çeşitlerindeki (ölçek etkinliği hariç) daha yüksek miktarda gerilemiştir (\% 7.3).

Sonuç olarak hem teknik etkinlikteki genel gerileme hem de teknolojik değişimdeki gerileme sonucu toplam faktör verimliliği düşmüştür. Yani hem teknik anlamda hem de beşeri anlamda ilerleme kaydedemeyen sektörde genel anlamda bir küçülme söz konusudur. Bu etkinin içinde sarf edilen aylak girdiler verimli çalışamayan iş gücü, işletme yönetim politikalarındaki problemler, iş gücü piyasasında kalifiye hale gelememe durumu ve daha birçok sayılabilecek aksaklıklar bulunmaktadir.

\section{Sonuç ve Öneriler}

CCR modelinden elde edilen sonuçlara göre etkin çıkan firmalar ölçeğe göre değişken getirili model olan BCC de etkin çıkmış ve buna ilaveten etkin çıkan firma sayısı azalan kısıt sayısı nedeniyle artmıştır. Yani örneklemde ölçek olarak etkin olmayan oldukça fazla sayıda firma bulunmaktadır. Çünkü sadece CCR yöntemine göre etkin olan firma sayısı toplam firma sayısının \%10’u kadar bile olamamıştır. BCC yönteminde ise etkin firma sayısı toplam firma sayısının \%14'ü seviyelerindedir. Bir diğer yandan genelde etkin firmalar haricinde firmaların hala ölçeğe göre artan getiride çalıştı̆̆ 1 da görülmektedir. Yani genel olarak firmaların hanelere taşıdıkları doğalgaz miktarı, kullandıkları girdilerden daha yüksek bir hızda artış sağlamaktadır. O nedenledir ki, etkinsiz olan firmaların hem çelik hem de polietilen boru hattı için yatırımlarına devam etmesi hem de personel sayısını da artırıcı uygulamalar sağlamasıyla görece etkinsizlikleri düzelmeye başlayacaktır.

Genel anlamda hem ülkemizin net ithalatçı oluşu hem de sektörün tehlike arz eden bir yapıda oluşu da doğal gaz piyasası için girdilerin özenle seçilmesi ve oluşturulması gerekmektedir. Öncelikli polietilen boru hattının ülkemiz coğrafik ve jeolojik konumuna uygun oluşu ve ekonomik maliyetlerinin düşüklüğü bu etkinsiz firmalar için uygun bir yatırım aracı olarak tercih edilebilmektedir. O nedenle boru hattındaki özellikle de polietilen boru hattındaki inşalara devam edilmesi yerinde olacaktır.

VZA ile analiz tamamladıktan sonra TFV hesaplamasına geçilmiş ve buradaki bulgulardan da anlaşıldığı üzere doğalgaz dağıtım sektörünün istikrarlı büyüyemediği ortaya çıkmıştır. Toplam faktör verimliliği içinde bulunan ölçek, saf ekonomik ve teknik anlamdaki etkinliklerin sağlanması da yine bilgi birikimi koşulunun sağlanması ile gerçekleşebilecektir. Özetle bu analiz de VZA analizini destekler nitelikte doğalgaz sektöründe hem fiziki hem de beşeri yatırımların devamının gerekliliğine dikkat çekmektedir.

Sektör niteliği ve ülke ekonomisindeki yeri nedeniyle gelir esnekliği düşük olan yani artık zorunlu bir mal haline gelmiş olan doğal gaz üretiminde çalışan kişilerin sayısının yanında bilgi birikiminin de önemli olduğu aşikârdır. Firma yöneticilerinden, mühendislere ve işçilere kadar hiyerarşik düzende tüm katmanlarda sağlanacak kalifiye eleman olgusu sektörün de niteliğini yükseltecek ve bir anlamda ülkemizin dışa bağımlı olduğu bu kaynağı daha düzenli ve efektif şekilde dağıtabilme ve tüketebilme durumu da sağlanmış olacaktır.

Tüm analizlerimizden hareketle hane halkı ısınma vb ihtiyacını gidermesinin yanı sıra aynı zamanda faktör (öncü) bir piyasa özelliği de gösteren doğalgaz dağıtım piyasasının arz ettiği hizmet aynı zamanda diğer birçok firma için de girdi niteliklidir. Yani bu piyasada yaşanacak bir gelişme birçok ardılı piyasayı etkileyebilme özelliğine sahiptir. Böylesine bir zincirleme etkiye sahip piyasanın etkin halde işlemesi de diğer birçok sektörün etkinliğini de artıracaktır. Kısacası günümüzde böylesine gereklilik arz eden ve artık olmazsa olmaz niteliği kazanmış bir enerji ürününün dağıtımında sağlanacak etkinlik genel anlamda toplumsal maliyeti azaltıcı dolayısıyla toplumsal refahı artırıcı yönde olacaktır. 
Hünerli, Ö., C., Aydın, Ü. / Journal of Yasar University, 2019, 14 (Special Issue), 133-146

\section{KAYNAKÇA}

Akal, Mustafa. 2015. Mikroekonomi; Tüketici, Üretici ve Piyasa Teorisi. No:40. İkinci Bask1, Ankara: Seçkin Yayınevi. Andersen, Peer ve Petersen, Niels Christian. 1993. "A Procedure for Ranking Efficient Unis in Data Envelopment Analysis". Management Science, 1993, vol. 39, issue 10, ss.1261-1264.

Aydın, Üzeyir ve Kök, Recep. 2013. “Türk Bankacılık Sektöründe Organizasyonel Etkinlik ve Etkinsizliğin Kaynakları”, Verimlilik Dergisi, 2013/3, ss.7-38.

Benli, Keskin, Yasemin. 2012. "Veri Zarflama Analizi (VZA) ve Malmquist Toplam Faktör Verimliliği (TFV): Konaklama İşletmelerinde Bir Uygulama", Ege Akademik Bakış, Cilt: 12, Sayı: 3, ss. 369-382.

Charnes A, Cooper, W.W., Lewin, A.Y and Seiford, L.M. 1994. "Data Envelopment Analysis: Theory, Methodology And Application”. Boston: Kluwer Academic Publishers.

Cingi, Selçuk ve Tarım, Ş. Armağan. 2000. "Türk Banka Sisteminde Performans Ölçümü DEA-Malmquist TFP Endeksi Uygulaması", Türkiye Bankalar Birliği Araştırma Tebliğleri Serisi, Sayı: 2000-01.

Demirci, Ayhan. 2018. Teori ve Uygulamalarla Veri Zarflama Analizi. Ankara: Gazi Kitabevi.

Dinçer. S.Erdal. 2011. Stratejik Planlama ve Veri Zarflama Analizinde Etkinlik Ölçümü. İstanbul. Der Yayınları.

Düzgün, Mustafa. 2011. Veri Zarflama Analiziyle Elektrik Dă̆ıtım Şirketlerinin Etkinlik ve Verimlilik Analizi. Yüksek Lisans Tezi. Ankara Üniversitesi Sosyal Bilimler Enstitüsü.

Erbetta, Fabrizio. ve Rappuoli, Luca. 2003. "Estimating Optimal Scale and Technical Efficiency In The Italian Gas Distribution Industry", Higher Education and Research On Mobility Regulation and The Economics Of Local Services. Working Paper: 6: ss. 2-19.

Joskow. Paul. L. 2007. Regulation of Natural Monopolies. A. Mithcell Polinsky \& Steven Shavell (eds). Chapter 16 in Handbook of Law and Economics, vol. 2, ss. 1227-1348 from Elsevier.

Karahan, Atila. ve Özgür. Ersan. 2009. Hastanelerde Performans Yönetim Sistemi ve Veri Zarflama Analizi. Ankara: Nobel Yayın Dağıtım, 2. Basım No:1418.

Kessides, Ioannis N. 2004. Reforming Infrastructure Privatization, Regulation and Competition: A World Bank Policy Research.

Kurtlar, Meral. ve Kartal. A. 2004. "Cumhuriyet Üniversitesinin Veri Zarflama Analizi: Fakülteler Düzeyinde Veri Zarflama Yöntemiyle Bir Uygulama”, Kocaeli Üni. Sosyal Bilimler Enst. Dergisi 2004 / 2: ss.49-79.

Marques. V., Almeida. M., Cunha. M., Paço., M,. Rocha. A. ve Trindade. A. 2011. What Drives Efficiency on the Portuguese Gas Distribution?, ss. 17-25

Ölmezoğulları, Nalan ve Çetin,Tamer. 2005. "Doğal Monopoller, Regülasyonu ve Rekabetçi Uygulamalar". İktisat, İsletme ve Finans Dergisi. Cilt: 20, ss.37-43.

Öncel, Abidin. ve Şimşek, Salih. 2011. “Türkiye'de Bölgelerarası Kaynak Kullanım Etkinliğinin Veri Zarflama Analizi Yöntemiyle Ölçülmesi”. Erciyes Üniv. İktisadi ve İdari Bilimler Fakültesi Dergisi. Say1: 37. Ocak-Haziran: 89

Özdemir, Zekai., Sever, Erşan., Mercan, Birol. Ve Ustaoğlu, Murat. 2013. Mikro İktisadi Analiz. Tablet Kitabevi Yayınları. Baskı: 2.

Storto, Corrado lo. 2014. "Gas Distribution in Italy: A Non Parametric Analysis of Companies Operational Efficiency". Advanced Material Research Vol. 838-841. Trans Tech. Publication Switzerland: 1972-1978.

T.C. Enerji Piyasasi Düzenleme Kurumu (EPDK). Doğal Gaz Piyasası Sektör Raporu (2011-2016), https://www.epdk.org.tr/Detay/Icerik/3-0-107/yillik-sektor-raporu, Erişim Tarihi: 08.08.2019.

Tarım. Ş. Armağan. 2001. "Veri Zarflama Analizi: Matematiksel Programlama Tabanlı Göreli Etkinlik Ölçüm Yaklaşımı”. Sayıştay Yayın İşleri Müdürlüğü Araştırma Dizi: 1: 11.

Yanes, L. 2013. "Stochastic Frontier Estimation for Gas Transmisson Pipelines” (Australia and United States Data). Acil Allen Consulting Dampier to Bunbury Pipeline. 19 September: 14.

Yücel, Leyla İşbilen. 2017. Veri Zarflama Analizi. Der Yayınları Sertifika No: 13773: 1.

Zorić, Jelena., Hrovatin, Nevenka. ve Scarsi, Gian Carlo. 2009. "Gas Distribution Benchmarking of Utilities from Slovenia, The Netherlands and The United Kingdom: An Application of Data Envelopment Analysis", South East European Journal of Economics and Business 4(1), ss.113-124. DOI: 10.2478/v10033-009-0008-1 · 